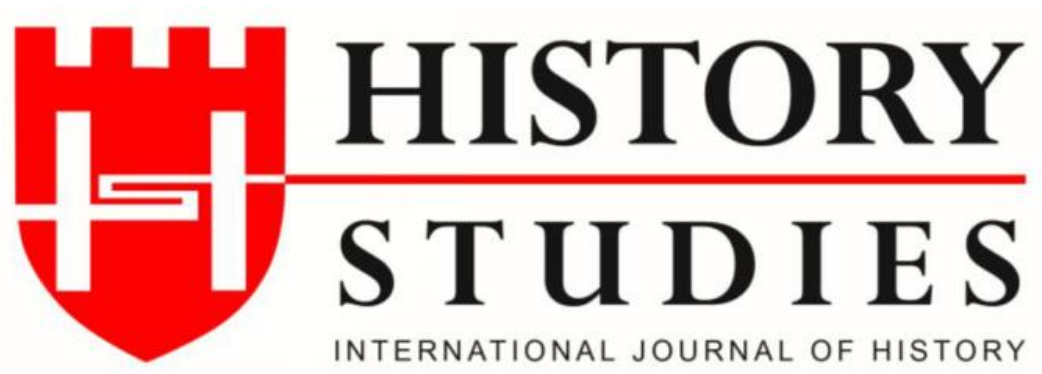

ISSN: 13094173 (Online) 1309 - 4688 (Print)

Volume 12 Issue 3, June 2020

DOI Number: 10.9737/hist.2020.872

Araştırma Makalesi

Makalenin Geliş Tarihi: 10.03.2020 Kabul Tarihi: 05.04.2020

Atıf Künyesi: Murat Alanoğlu, "17. Yüzyıl Ortalarında Varto (Yerleşim, Nüfus, Vergi ve Aşiretler)”, History Studies, 12/3, Haziran 2020, s. 1143-1175.

\title{
17. Yüzyıl Ortalarında Varto (Yerleşim, Nüfus, Vergi ve Aşiretler)
}

\author{
Varto in The Middle of The $17^{\text {th }}$ Century \\ (Settlement, Population, Taxes and Tribes)
}

\author{
Dr. Murat Alanoğlu \\ ORCID No: 0000-0003-3631-6923 \\ Muş Alparslan Üniversitesi
}

Volume 12 Issue 3
Öz: Çaldıran Savaşı'ndan kısa bir süre sonra Osmanlı hâkimiyetine giren Varto bölgesi, Hınıs ve Handırıs ile birlikte Bitlis sancağına bağlandı. 1540 yılına kadar Bitlis sancağına bağlı kalan Varto, Erzurum eyaletinin teşkili ve Hınıs'ın buraya tabi bir sancak haline getirilmesinden sonra Hınıs'ın bir nahiyesi haline getirildi. Varto'nun Hınıs'ın nahiyesi olarak idari teşkilattaki varlığ 1 19. yüzyıl ortasına kadar devam etti. 19. yüzyıl ortalarında Muş’a bağlanan Varto, önce nahiye daha sonra kaza olarak idare edildi. Bu çalışmada, günümüzde Muş'a bağlı bir ilçe merkezi olan Varto'nun 17. yüzyıl ortalarındaki idarî, sosyal, yerleşim, nüfus ve aşiret yapısı dört avârız defterine (1642, 1643, 1645 ve 1650) göre incelenmiştir. 17. yüzyılda Varto'da kaç köy olduğu, bu köylerde kimlerin veya hangi aşiretlerin yaşadığı, devlet merkezine ne kadar vergi verdikleri sorularına cevap aranmıştır. Ayrıca 16. yüzyıla ait tahrir defteri verileri kullanılarak iki yüzyıl arasında karşılaştırmalar da yapılmıştır.

Anahtar Kelimeler: Varto, Osmanlı, Erzurum, Muş, Hınıs, Avârız

Abstract: The Varto region, which came under Ottoman rule shortly after the Battle of Çaldıran, was connected to the sanjak of Bitlis with Hinis and Handirls. Varto, which remained under the sanjak of Bitlis until 1540, was transformed into a sub-district of Hinıs after the formation of the province of Erzurum and the transformation of Hinıs into a sanjak of it. Varto's presence in the administrative organization as the sub-district of Hinis continued until the mid $-19^{\text {th }}$ century. Being connected to Mush in the mid- $19^{\text {th }}$ century, Varto was first ruled as a sub-district and then as a district. In this study, the mid- $17^{\text {th }}$ century administrative, social, settlement, population and tribal structure of Varto, which is currently a central district of Mush, was examined according to four avârlz registers (1642, 1643, 1645 and 1650). Answers for the questions "How many villages were there in Varto in the $17^{\text {th }}$ century?", "Who or what tribes lived in these villages?", and "How much tax did they pay the state center?" were sought. In addition, comparisons were made between the 16 th and $17^{\text {th }}$ centuries by using the $16^{\text {th }}$ century tahrir registers data.

Keywords: Varto, Ottoman, Erzurum, Mush, Hınıs, Avârız

History Studies 
Giriş

Osmanlı belgelerinde Varto adına ilk defa 1544 yılına ait bir defterde rastlanmaktadır. Burada Erzurum eyaletinin Hınıs sancağına bağlı olan Varto, "Handırıs nâm-ı diğer Varto" şeklinde kaydedilmiştir. Bu kayıtta geçen "Handırıs nâm-ı diğer Varto" ifadesinden Varto ile Handırıs'ın ${ }^{1}$ aynı bölge olduğu ve isimlerinin birlikte kullanıldığı anlaşılmaktadır. ${ }^{2}$ Daha sonra

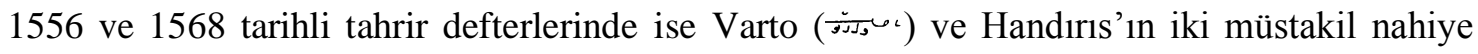
şeklinde kaydedildiği görülmektedir. ${ }^{3}$ Burada Varto bir yerleşim yerinden ziyade bir bölge adı olarak kullanılmıştır. Zira Varto ismini taşıyan herhangi bir köy veya kasaba kayıtlara geçmemiştir. Buna karşın Osmanlı belgelerinde Varto bölgesi merkezinin Gümgüm ( köyü olduğu açıkça belirtilmiştir. ${ }^{4}$ Dolayısıyla geçmişte olduğu gibi günümüzde de halk arasında Varto için Gımgım/Gümgüm tabiri kullanılmaktadır.

Varto adının kaynağına dair birkaç görüş bulunmaktadır. Bunlardan ilki Varto'da önemli yerleşimleri görülen Urartulardan dolayı Urartu/Orarto adının bozulmuş biçimi olarak Varto'nun ortaya çıktığ 1 şeklindedir. ${ }^{6}$ Diğer görüş ise Varto'da ilk yerleşimi kuran Ermeni prensi Vartan'ın adına izafeten bölgeye Varto denilmiştir. Halk arasında yaygın bir kanaate göre Varto adı, Zazaca "Vare-to (Senin Yaylan)" sözcüğünün değişime uğramış halidir. ${ }^{7}$

Varto bölgesi, 1514’te Osmanlıların üstünlüğüyle neticelenen Çaldıran Savaşı’ndan birkaç yıl sonra Osmanlı idaresine girdi. ${ }^{8}$ Kısa bir süreliğine tekrar Safevilerin eline geçse de Osmanlı hâkimiyetinin tesis edilmesi gecikmedi. $1535^{\prime}$ ten sonra kati şekilde Osmanlı yönetimine giren Varto, 1540'a kadar Diyarbekir beylerbeyliğine tabii olan Bitlis hükümetine/sancağına bağlandı. $\mathrm{Bu}$ durum 1537 tarihli Bitlis icmal tahrir defterinden tespit edilebilmektedir. $\mathrm{Bu}$ tarihte Varto nahiyesi henüz teşkil edilmediğinden Varto'ya ait köyler defterde Handırıs nahiyesi altında kaydedilmiştir. ${ }^{9}$ Daha sonra Erzurum beylerbeyliğinin teşkili ve Hınıs'ın

${ }^{1}$ Handırıs, Varto'nun doğusunda Bulanık'ın batı sınırından başlayarak güneyde Karasu Nehri'ni takip ederek Muş’un kuzeyi boyunca günümüz Yaygın ve Mercimekkale beldelerini içine almaktaydı. 1892 tarihli Bitlis salnâmesinde Handırıs nahiyesinin sancak merkezinin Muş'a 4, vilayet merkezi Bitlis'e 16 saat mesafede olduğu kayıtlıdır. Bkz. Sâlnâme-i Vilâyet-i Bitlis, 1310, s. 203; Şeyh İdris'e izafeten Endiris veya İdris'in köyü şeklinde de ifade edilen Handırıs'ın veya bazı kaynaklarda Handeresi şeklinde geçen yerleşim yerinin Bulanık'a bağlı Sıradere köyü olduğu belirtilmektedir. Bkz. https://nisanyanmap.com/?yer=25708\&haritasi=s\%C4\%B1radere Erişim tarihi: 30.11.2019

${ }^{2}$ BOA, MAD. $d$, nr. 22171, s. 69. Defterde bazı sayfalar eksik olduğundan ve yanlış ciltlendiğinden Varto ve Handırıs'a ait köyler 25. sayfadan itibaren başlamaktadır.

${ }^{3}$ BOA, TT. $d$, nr. 294, s. 63.

4 “Muş sancağına tabi Varto kazasının merkezi bulunan Gümgüm karyesi ...”. BOA, BEO, nr. 13/944; “ ... Bu kazanın makarr-1 idâresi Gümgüm Kasabası'dır”. Bkz. Sâlnâme-i Vilâyet-i Bitlis, 1310, s. 216; Varto yerine Gümgüm isminin geçtiği erken tarihli diğer iki belge için ayrıca bkz. BOA, HAT, nr. 769/36172; 814/37264.

${ }_{6}^{5}$ Mustafa Özbey, Osmanlı Belgelerinde Varto İlçesi, Doz Yayınları, İstanbul 2010, s. 13.

${ }^{6}$ Varto'nun güneydoğusunda yer alan Kayalıdere köyü önemli bir Urartu yerleşimidir. Bkz. C. A. Burney, “A First Season of Excavations on the Urartian Citadel of Kayalıdere”, Anatolian Studies, 16 (1966), s. 55-111.

${ }^{7}$ M. Şerif Fırat, Doğu Illleri ve Varto Tarihi, Kamer, İstanbul 1998, s. 82-83; Christopher de Bellaigue, İsyan Toprakları: Türkiye'nin Unutulmuş Halkları Arasında, İletişim Yayınları, İstanbul 2016, s. 44.

${ }^{8} 1518$ tarihli Diyarbekir tahrir defterinde Varto'ya ait bazı köyler Diyarbekir beylerbeyliğine bağlı Kiğı sancağında kaydedilmiştir. Yani ilk tahrir ve idari taksimata göre Varto'nun batı bölgesi Kiğı sancağının sınırlarına dâhildir. Bkz. BOA (Devlet Arşivleri Başkanlığı Osmanlı Arşivi), TT. d,(Tapu Tahrir Defteri) nr. 64, s. 731; D. Aydın'a göre Yavuz Sultan Selim döneminde Osmanlı'nın doğu sınırı Varto'nun doğusundan başlayarak Bingöl Dağları'na kadar uzanmaktaydı. Bkz. Dündar Aydın, Erzurum Beylerbeyliği ve Teşkilatı Kuruluş ve Genişleme Devri (1535-1566), TTK, Ankara 1998, s. 45.

9 BOA, $T$ T. $d$, nr. 189 , s. 28-34. 
buraya bağlı bir sancak haline getirilmesinden sonra Varto, Erzurum eyaletine aktarıldı. Nitekim idari taksimatı gösteren defterlerde görüldüğü üzere 1540'tan 19. yüzyıl ortasına kadar Varto, Erzurum eyaletinin Hınıs sancağına bağlı bir nahiye olarak varlığını sürdürdü.

19. yüzyıl ortalarına gelindiğinde Varto'nun yüzyıllardır devam eden idari yapısında bir takım değişikliklere gidildi. Hınıs ile bağlantısı kesilen Varto, Muş sancağına bağlı bir nahiye ve daha sonra kaza merkezi haline getirildi. Varto'nun idari değişikliğinin nedeni Muş'un yeniden teşkilatlandırılması olmalıdır. Zira birkaç yüzyıldır Van eyaletine bağlı olan Muş, Erzurum eyaletine aktarıldı. ${ }^{10}$ Nitekim 1847-1848 yılına ait devlet salnamesinde, Muş livası Erzurum eyaletine bağlıdır. ${ }^{11} 1856$ tarihli belgelerde Varto'nun "Vartolar kazası" adıyla Muş sancağına bağlı olduğu görülmektedir. ${ }^{12}$ Zira 1870-1876 tarihli Erzurum vilayet salnamelerine göre Varto kazası, Muş sancağına tabi Varto-yı Ulya ve Varto-yı Süfla ${ }^{13}$ şeklinde adlandırılan bir kaza merkeziydi. ${ }^{14}$ Bir süre bu şekilde yönetildikten sonra Muş'la ilgili idari teşkilatta yapılan yeni düzenlemelerden dolayı Varto kazası, 1877'den itibaren Erzurum'dan ayrılarak Bitlis vilayetinin Muş sancağına bağlanmıştı. Bu değişiklik akabinde 1892, 1894, 1898, 1899 , 1900, 1901 ve 1902 yıllarına ait Bitlis vilayet salnamelerinde Muş sancağına bağlı olan Varto kazası Üstükran-1 Ulya ve Karaköy nahiyelerinden oluşmaktadır. ${ }^{15}$ Yüzlerce yıl bölge adı olarak kullanılagelen Varto, 1923 y1lında resmi ilçe statüsü kazandı. 1928 y1lı itibariyle köy isimlerini içeren çalışmada Bitlis vilayetine bağlı Varto kazası, merkez nahiye Gümgüm, Üstükran ve Karaköy olmak üzere üç nahiyeden ve toplam 105 köyden ibaretti. ${ }^{16}$

Günümüzde Doğu Anadolu bölgesinin Yukarı Murat-Van havzasında yer alan Varto, Muş

Volume 12 Issue 3 June 2020 iline bağlı yedi mahalle ve 93 köyden oluşan bir ilçe merkezidir. Varto'yu kuzeyden Erzurum'un Hınıs ve Tekman ilçeleri, güneyden Muş merkezi, batıdan Bingöl'ün Solhan ve Karlıova ilçeleri ve doğudan Muş'un Bulanık ilçesi çevrelemektedir. ${ }^{17}$ Varto, güney ve kuzeyini saran Şerafettin ile Bingöl gibi iki yüksek dağın arasındaki platolar ve hafif düzlüklerden oluşmaktadır. Bu düzlükler Varto'da yerleşimin, doğu-batı istikametinde oluşmasına neden olmuştur. Bu ovalardan ilki, bölgede hâkim olan aşiretten adını alan, Hormek düzüdür. Burası daha ziyade Üstükran nahiyesi sınırları içerisindedir. Bu bölgenin güneyinde uzanan bir diğer ova alanı ise Gundemir düzüdür. Bu düzlükte dört köy bulunmakta ve alüvyonlu toprakları oldukça verimlidir. Hormek düzünün doğusunda yayvan ve alçak şekilde uzanan bir diğer düzlük alan ise günümüz ilçe merkezinin yayıldığı Gümgüm Ovası’dır. Bu dağlık kesimin hemen altındaki Göşker köyünün altından başlar, Göşker Deresi boyunca

\footnotetext{
${ }^{10} 1831$ tarihinde Muş hâlâ Van eyaletinin livalarından biridir. Bkz. Fazıla Akbal, "1831 Tarihinde Osmanlı İmparatorluğu'nda İdari Taksimat ve Nüfus", Belleten, 15/60, Ankara 1951, s. 626.

${ }^{11}$ Sâlnâme-i Devlet-i Aliyye-i Osmaniyye, 1263/1847, s. 75, 87; Sâlnâme-i Devlet-i Aliyye-i Osmaniyye, 1264/1848, s. 119.

12 “Muş sancağı Vartolar kazası müdürü ...”. Bkz. BOA, A. MKT. MVL, nr. 85/57, 85/8; BOA, A. AMD, nr. 86/6.

${ }^{13}$ Ulya: Yukarı, Süfla: Aşağ

${ }^{14}$ Sâlnâme-i Vilâyet-i Erzurum, 1287/1870, s. 79; Sâlnâme-i Vilâyet-i Erzurum, 1288/1871, s. 78; Sâlnâme-i Vilâyet$i$ Erzurum, 1289/1872, s. 81; Sâlnâme-i Vilâyet-i Erzurum, 1290/1873, s. 105; Sâlnâme-i Vilâyet-i Erzurum, 1291/1874, s. 105; Sâlnâme-i Vilâyet-i Erzurum, 1292/1875, s. 100, Sâlnâme-i Vilâyet-i Erzurum, 1293/1876, s. 87.

${ }^{15}$ Sâlnâme-i Vilâyet-i Bitlis, 1310, s. 215-219.

${ }^{16}$ Dâhiliye Vekâleti, Son Teşkilât-1 Mülkîyede Köylerimizin Adları, Millet Matbaası 1928, s. 433-435. Varto kazası nahiyelerinden Gümgüm'de 44, Üstükran'da 39 ve Karaköy'de 22 köy bulunmaktaydı.

${ }^{17}$ Yasin Güler, Varto Kasabasının Coğrafi Etüdü, Yayımlanmamış Yüksek Lisans Tezi, Atatürk Üniversitesi, Sosyal Bilimler Enstitüsü, Erzurum 2003, s. 1; http://www.mus.gov.tr/varto-mus Erişim Tarihi: 30.11.2019.
} 
uzanan bu alan Hirsızkale Tepesi'ne kadar devam eder. Varto'nun dördüncü ovalık alanı ise Göşker suyunun Murat Nehri'ne karıştığı Çaherbehor köyünde bulunan Tavkıran düzüdür. Bu düzlükler Murad Nehri ile Göşker, Baskan, Sofyan, Hoşan, Sorpalağ, Çeharbehor ve Akdoğan dereleri tarafından sulanmaktadır. Varto'un yükseltisi, taşlık yapısı ve iklimi verimli tarım üretimine imkân vermediğinden yaylalar ile çayır alanlarda küçük ve büyükbaş hayvancılık temel geçim kaynağına dönüşmüştür. ${ }^{18}$

Varto'nun idarî ve coğrafi yapısına dair bu kısa girişten sonra çalışmanın kaynaklarına değinilerek asıl konuya geçilecektir.

\section{I. Çalışmanın Kaynakları}

16. yüzyıl Osmanlı sosyal, ekonomi ve demografi tarihinin temel kaynakları tahrir defterleridir. Fakat 17. yüzyıldaki iktisadî, askerî ve sosyal değişim nedeniyle timar sisteminin yerini iltizama bırakmasıyla, bazı istisnalar dışında, klasik timar tahririnden vazgeçildi. Ancak klasik tahrir yerini devletin önemli vergi kalemlerinden biri haline avarız sayımlarına bıraktı. Dolayısıyla 17. yüzyılda nüfus, yerleşim, sosyal yapı hakkında bilgi alabileceğimiz en önemli kaynak avârız vergisi tahrirlerini içeren avârız defterleridir. Zira mufassal avârız defterleri 17. yüzyıl Osmanlı demografi ve iskân tarihi için bir hayli önemlidir. ${ }^{19}$ Bu çalışmanın temel kaynağı olan 1642 tarihli Erzurum eyaleti mufassal avârız defteri, Devlet Arşivleri Başkanlığı Osmanlı Arşivi, Maliyeden Müdevver Defterler Kataloğu (MAD. d.) 5152 numarada kayıtlıdır. Defterin birinci sayfasında mahallinde hıfz oluna kaydından sonra icmâl başlığı ile Erzurum eyaletine bağlı on dört kazanın adı ve bu kazaların yer aldığı sayfa numaraları verilmiştir. Defterin ikinci sayfasında defterin ne zaman ve niçin tutulduğuna dair şu kayıt yer almaktadır: "Bî-avni'llahi te 'âla, defter-i hânehâ-i eyâlet-i Erzurum ki be-mübâş̧eret-i hakîr hâlâ müceddeden tahrîr kerden fermûde ber mûceb-i fermân-ı âli tahrîr şüd el-vâki' fî evâil-i şehr-i Cemâziye'l-ûlâ sene isnâ ve hamsîn ve elf'. Bu kayittan Sultan İbrahim'in emriyle evâili Cemaziyel-evvel 1052/28 Temmuz ve 6 Ağustos 1642 tarihleri arasında Erzurum eyaletinin tahrir işlemine tabi tutulduğu anlaşılmaktadır. Bu mufassal avârız defterinde, Defter-i hânehâ-i eyâlet-i Erzurum başlığı altında Erzurum eyaletine bağlı sancaklar kaza adı altında kaydedilmiştir. Bunlar sırasıyla Erzurum, Erzincan, Bayburd, Şiryan, Hınıs, İspir, Kelkid, Kemah (Gercanis ve Kuruçay), Kızuçan, Kiğı, Koğans, Pasin, Tercan ve Tortum kazalarıdır. ${ }^{20}$

\footnotetext{
${ }^{18}$ Hüseyin Saraçoğlu, Doğu Anadolu, C. 1, Maarif Yayınevi, İstanbul 1956, s. 364-366; Yasin Güler, Varto Kasabasinin Coğrafi Etüdü, s. 4, 24-25.

${ }^{19}$ Oktay Özel, “Avârız ve Cizye Defterleri”, Osmanlı Devleti’nde Bilgi ve İstatistik, Ed. Halil İnalcık-Şevket Pamuk, Ankara, 2000, s. 35; Oktay Özel, "17. Yüzyıl Osmanlı Demografi ve İskân Tarihi İçin Önemli Bir Kaynak: Mufassal Avârız Defterleri”, XII. Türk Tarih Kongresi (12-16 Eylül 1994) Kongreye Sunulan Bildiriler, C. III, Ankara 1999, s.738-739.

${ }^{20}$ BOA, MAD. d. 5152, s. 1-1120. Bu defterdeki kazalar birçok araştırmaya konu olmuştur. Öncelikle defteri ilk defa kullanan Prof. Dr. Mehmet İnbaşı'yı anmak gerekir. İnbaşı, defterin Erzurum, Bayburt ve Erzincan kazalarının verilerini birer makale ile ortaya koymuştur. Daha sonra Gümüşhâne'yi (Torul) Bilgehan Pamuk; İspir'i İbrahim E. Çakır; Kelkit'i Selçuk Demir ve İbrahim E. Çakır; Koğans'1 Alparslan Demir, Şiryan'ı Eyüp Kul, Kızuçan'1 Murat Alanoğlu, Gercanis ve Kuruçay’ı Adem Başıüyük çalışmıştır. Yazarları belirtilen çalışmaların künyesi kaynakçada yer almaktadır. Ayrıca defterin Erzurum merkez kısmı ve birkaç kazasının transkripsiyon yayını 2014 yılında yapılmıştır. Bkz. Mehmet İnbaş1-İbrahim E. Çakır-Selçuk Demir, 1642 Tarihli Erzurum Eyaleti Mufassal Avârız Defteri I (Erzurum-Tortum-İsbir-Hınıs -Pasin), TTK, Ankara 2014. Mezkur çalışmada Varto köy adları ve aşiret isimlerinde kimi farklı okumalar tespit edildiğinden makalemizde, saha araştırmaları ile teyit edilen kendi okumalarımız tercih edilmiş ve defterin orijinal sayfasına atıf yapılmıştır.
} 
Defterin tamamı 1120 sayfadan oluşmaktadır. Bu çalışmanın konusu olan Varto nahiyesi, defterin 877-890. sayfaları arasında yer almaktadır. ${ }^{21}$ Varto nahiyesine ait olan bu kısım "Nahiye-i Varto tabi ${ }^{\prime}-i$ Hınıs" ifadesi ile başlamaktadır. Varto nahiyesinin nefs tabir edilen şehir merkezinin olmaması, askeri ve dinî görevlilerin sayısının da az olmasından dolayı doğrudan nahiyeye bağlı köylerin yazımına geçilmiştir.

Mufassal olarak hazırlanan defterler, kadılar tarafından devlet merkezine gönderilerek avarız işlerine bakan Mevkufat Kalemi'nce kaydedilirdi. Burada, mufassal defterden ayrı olarak maliyede pratik kullanım için kazaların mahalle ve köyler esasına göre avârızhâne toplamlarını gösteren bir de icmal defteri hazırlanırdı. ${ }^{22}$ Nitekim 1642 tarihli bu defterden bir yıl sonra Erzurum eyaletine ait bir icmâl defter düzenlenmiştir. 1643 tarihli bu icmâl defter Başbakanlık Osmanlı Arşivi'nde MAD. d. 6422 numarada kayıtlıdır. Bu defterdeki Varto nahiyesi verileri 57-58. sayfa aralı̆̆ında yer almaktadır. ${ }^{23}$

1642 tarihindeki tahrir işlemi Erzurum eyaletinin cizye ve avârız muharriri Cafer Efendi tarafından yapılmıştı ve bu sayım mufassal olarak kayda geçirilmişti. ${ }^{24}$ Daha sonradan 1645 ve 1650'de Cafer Efendi tarafından 1642 verilerinin iki defa güncellendiği ve merkeze bildirildiği görülmektedir. İlk tahrirden üç yıl sonra 1645 'de yapılan avârız sayımı, Erzurum bölgesinde meydana gelen "taunun (veba)" nüfusa ve vergiye bir etkisinin olup olmadığını öğrenmek isteyen devlet merkezinin isteği üzerine yapılmıştı. Cafer Efendi, hazırladığ 1 defterin sonuna Erzurum eyaletindeki vebanın hane sayısını etkilemediği ve mevcut avârızhane vergisinin toplanabileceği kaydına yer vermişti. ${ }^{25}$ Nitekim defterin hemen başında yer alan kayıtta da Erzurum eyaletinde meydana gelen veba salgını nedeniyle bazı kimselerin ölmesi ve bazı hanelerin harap olmasından dolayı bölgede yeniden tahrir yapma gereğinin ortaya çıktığı anlaşılmaktadır. Buna istinaden Cafer Efendi tekrar görevlendirilmişti. Zira avârız ve nüzûl akçesinin toplanıp toplanamayacağı merak ediliyordu. Bunun üzerine deftere yansımamış yerleri de eklemek suretiyle sağlam bir sayıma girişen Cafer Efendi, vebaya maruz kalmayan ve daha önce kayda geçmeyen yerlerden eksikleri kapatmak suretiyle Erzurum genelinde bulunan 1.100 haneden 16.900 akçe vergi kaydetmişti. Bu rakam zaten 1642'deki sayım ile aynıydı, dolayısıyla veba salgını nedeniyle devletin bir kaybının olmadığı ve avârız ile nüzûl vergisinin toplanabileceği devlet merkezine bildirilmişti. ${ }^{26} 1645^{\prime}$ deki sayımda bazı köylerden fazla vergi talep edilmiş olacak ki 1650 'de yapılan üçüncü tahrirde devlet merkezindeki Mevkufat Kalemi'nce bazı köylerde hane sayısının düşürülmesi talep edilmişti. İşte veba sebebiyle Cafer Efendi'nin yaptığı ikinci sayımın kayıtlarını içeren diğer avârız tahriri MAD. d. 14739 numaralı 1645 tarihli defterdir. Bu defterde "Nahiye-i Varto der-kazâ-i Hınıs" başlığı altındaki Varto köyleri 43-44. sayfalar arasında yer almaktadır. ${ }^{27}$ Cafer Efendi'nin yaptığı üçüncü tahririn icmal avârız defteri MAD. d. 14933 numaralı ve 1650 tarihlidir. Bu defterde

\footnotetext{
${ }^{21}$ Varto nahiyesinin bağlı olduğu Hınıs kazasına ait kısım 846-890. sayfalar arasındadır. Defterde Hınıs kazası, Hınıs, Bulanık ve Varto nahiyelerinden oluşmaktadır.

${ }^{22}$ Feridun M. Emecen, "Kayacık Kazâsı Avârız Defteri”, Tarih Enstitüsü Dergisi, sayı 12, İstanbul 1981-1982, s. 160; Linda T. Darling, Gelir Artışı ve Kanuna Uygunluk, Osmanlı Imparatorluğunda Vergi Toplanması ve Maliye Yöntemi 1560-1660, Çev. Adnan Tonguç, Alfa, İstanbul 2019, s. 44-45.

${ }^{23}$ BOA, MAD. $d$, nr. 6422, s. 57-58.

${ }^{24}$ Cafer Efendi adına Erzurum'da inşa edilmiş ve Caferiye Camii adını taşıyan bir camii ve buraya vakfedilmiş çok sayıda vakıfları vardı. Cafer Efendi hakkında bilgi için bkz. Ümit Kılıç, "Erzurum’da Câfer Efendi Vakfi”, A.Ü. Türkiyat Araştırmaları Enstitüsü Dergisi, sayı 41, Erzurum 2009, ss. 173-187.

${ }^{25}$ BOA, MAD. $d$, nr. 14739, s. 50.

${ }^{26}$ BOA, MAD. d, nr. 14739, s. 1, 50; Bilgehan Pamuk, XVII. Yüzyılda Bir Serhad Şehri Erzurum, IQ Kültür Sanat Yayıncilik, İstanbul 2006, s. 126.

${ }^{27}$ BOA, MAD. $d$, nr. 14739, s. 43-44.
} 
"Nahiye-i Varto" başlı̆̆ı ile kaydedilen Varto'ya ait köyler ise 49-50. sayfalarda yer almaktadır. ${ }^{28}$

$\mathrm{Bu}$ defterlerin yanı sıra daha erken bir zamana tarihlendirilmiş eksik bir defter de mevcuttur. 1020/1611-1612'ye tarihlendirilen D. MKF. d. 31738 numaralı defterin bazı sayfalarının kopmasından dolayı Varto'ya ait tek yaprak elimize ulaşmıştır. Bu sayfada Hınzori, Üçbudak, İnak, Köprü, Karçigay, Satışeyh, Gümgüm ve Gestmerd olmak üzere sekiz köy yer almaktadır. Ancak bu defterdeki köylerin sırası, köy ve avârızhane sayıs1 1642 tarihli defterin icmali ile birebir uyuşmaktadır. Dolayısıyla bu defterlerin birbirlerinin kopyası olma ihtimali yüksektir. Bununla birlikte küçük bazı rakam farklılıklarına da rastlanmaktadır. ${ }^{29}$

Yukarıda sıralanan 17. yüzyıla ait avârız defterlerinin yanında bir önceki yüzyıla ait nüfus ve yerleşim kayıtlarını ihtiva eden tahrir defterleri de bulunmaktadır. Hem karşılaştırma yapmak hem de nüfus ve yerleşim alanlarındaki değişimleri takip etmek üzere bu kaynaklara da müracaat etmek gerekmektedir. Varto'ya dair verileri içeren ilk defter 1537 tarihli TT. d. 189 numaralı Bitlis icmal tahrir defteridir. Bu defterde 1537'de Bitlis'e bağlı Hınıs, Varto, Handırıs ve Bulanık'a ait köyler kaydedilmiştir. ${ }^{30}$ Varto'ya dair bilgiler ihtiva eden ikinci kaynak ise 1544 tarihli ve MAD. d. 22171 numaralı tahrir defteridir. Karışık olarak ciltlendiğinden dolayı sayfalarda atlamalar ve eksikler mevcuttur. Varto ve Handırıs'a ait köyler 25-46. sayfalar arasında yer almaktadır. ${ }^{31}$ Varto'ya dair en ayrıntılı kayıtların bulunduğu ilk defter esasen 1556 tarihli tahririn kayıtlarını içeren TT. d. 294 numaralı Hınıs sancağı mufassal defteridir. Hınıs'a bağlı bir nahiye olan Varto'ya ait köyler defterin 63-91. sayfalarında bulunmaktadır. ${ }^{32}$ Varto verilerini barındıran bir diğer kaynak II. Selim döneminde yapılan tahririn bilgilerini içeren Tapu Kadastro Genel Müdürlüğü Arşivi'nde mahfuz 1568 tarihli TT. d. 70 numaralı Hınıs sancağı mufassal tahrir defteridir. Hınıs'ın bir nahiyesi olan Varto'ya ait bilgiler, "Nâhiye-i Varto Tâbi'-i Livâ-i Hinıs" başlığıyla 26-41. sayfalar arasında yer almaktadır. ${ }^{33}$ Yine bu mufassal defterin timar dağıtım düzenini gösteren TT. d. 231 numaralı icmal defterde Varto'ya dair bilgiler 28-38. sayfa aralığında bulunmaktadır. ${ }^{34}$

Bu kaynakların dışında Osmanlı Arşivi'nde yer alan mali ahkâm kayıtları ve sair müteferrik evraktan da Varto ile ilgili olan kimi belgelere başvurulmuştur. Kaynakların söz konusu tanıtımından sonra bu çalışmanın asıl konusunu teşkil eden nüfus, yerleşme ve aşiretler özelinde toplumsal hayata dair bilgilere geçilebilir.

\section{17. Yüzyılda Varto Nüfusu}

1642 tarihli defterde Varto merkezini (nefs) teşkil eden bir yerleşim birimi olmadığından nahiyedeki köylerin yazımına geçilmiş ve her bir köyde yaşayan hane sahibi erkekler ve babalarının isimleri deftere kaydedilmiştir. Müslümanların yaşadığı köyleri belirtmek için köy adının yanında "Müslümânân" kaydı, gayrimüslimlerin yaşadığını belirtmek için ise

${ }^{28}$ BOA, MAD. $d$, nr. 14933 , s. 49-50.

${ }^{29}$ BOA, D. MKF. d, nr. 31738, s. 20.

${ }^{30}$ BOA, TT. $d$, nr. 189 , s. s. 28-34.

${ }^{31}$ BOA, MAD. $d$, nr. 22171, s. 25-46.

${ }^{32}$ BOA, TT. d, nr. 294, s. 63-91. Defterin Osmanlı Arşivi'nce yapılan yayını için bkz. 294 Numaralı Hınıs Livâsı Mufassal Tahrir Defteri (963/1556), Ankara 2000.

${ }^{33}$ BOA, TT. $d$, nr. 70, s. 26-41.

${ }^{34}$ BOA, TT. $d$, nr. 231, s. 28-38. 
"zımmiyân" tabiri yazılmıştı. Eğer bir köyde Müslümanlar ile gayrimüslim birlikte yaşıyorsa önce Müslümanân başlığıyla Müslümanlar daha sonra "hanehâ-i zimmiyân" başlığıyla gayrimüslimler kaydedilmişti. Aşiretlerin yaşadığı köylerde ise köy adının yanına "an cemâat-i Zikdili/Banûkî/Süveydi/Pisyan" ifadesi konulmuştu.

1642'de Varto köylerindeki nüfus dağılımına bakıldığında kayıt yapılan 35 köyün 31'inde sadece Müslümanlar, diğer üçünde gayrimüslimler ikamet etmekteydi. Yalnız bir köyde Müslümanlar ile gayrimüslimler beraber yaşamaktaydı. Her ne kadar zımmî adı altında tasnif edilen gayrimüslim grubun hangisi olduğu belirtilmemişse de kaydedilen kişilerin isimlerine bakıldığında bunların Ermeni olduğunu söylemek mümkündür. Buna göre Ermeniler, Satışeyh köyünde 13, Gümgüm köyünde dört, Karakurd köyünde 14 ve Kalacık köyünde bir hane olmak üzere toplam 32 haneydi. Buna karşın 32 köyde yerleşik oldukları görülen Müslümanların en kalabalık oldukları köyler 21 hane ile Hınzori, 18 hane ile Alibijan ve 16 hane ile Dodan'dı. Seyrek nüfuslu olduğu görülen diğer köylerle birlikte Müslüman hane sayısı toplamda 243’tü. Müslümanlar ile gayrimüslimlerin birlikte yaşadığı tek köy Kal'acık olup burada dört Müslüman ile bir gayrimüslim hane yaşamaktaydı. Dolayısıyla her iki dinî grup arasında keskin bir mekânsal ayrımın mevcut olduğunu iddia etmek mümkündür. Toplam nüfus miktarına bakıldığında ise 1642 yılında Varto'da Müslüman nüfusun gayrimüslimlere oranla çok fazla olduğu görülmektedir. Müslümanların hangi etnik ve mezhebi gruba ait olduklarına dair herhangi bir kayıt bulunmamaktadır. Aşağıdaki tablo ve grafikte köy sayısı, köyde yerleşik hane miktarı ve bu hanelerin dinî dağılımı görülebilmektedir.

\section{Tablo-1: 1642 Tarihli Mufassal ve 1643 Tarihli İcmal Deftere Göre Varto'daki Köy ve Hane Sayıları}

\begin{tabular}{|c|c|c|c|c|c|}
\hline & \multirow[b]{2}{*}{ Köy Adı } & \multirow[b]{2}{*}{ Köyün Yeni Adı } & \multicolumn{2}{|c|}{1642} & \multirow{2}{*}{$\begin{array}{l}1643 \\
\text { Hane } \\
\text { Sayıs }\end{array}$} \\
\hline & & & $\begin{array}{c}\text { Müslim } \\
\text { Hane }\end{array}$ & $\begin{array}{c}\text { Gayrimüslim } \\
\text { Hane }\end{array}$ & \\
\hline $\mathbf{1}$ & Hınzori (Aşağı ve Yukarı) & Kayalıdere ve Kayalıkaya & 21 & - & 28 \\
\hline 2 & Üçbudak & Çayönü & 9 & - & 10 \\
\hline 3 & İnak & Yenimahalle & 6 & - & 6 \\
\hline 4 & Kirs & Boylu & 2 & - & 9 \\
\hline 5 & Karçıgay & Seki & 5 & - & 5 \\
\hline 6 & $\mathrm{~S}(\mathrm{Z})$ atışeyh & Acarkent & - & 13 & 19 \\
\hline 7 & Gümgüm & Gümgüm (Varto merkezi) & - & 4 & 4 \\
\hline 8 & Gestmerd & Çobandağ1 & 4 & - & 4 \\
\hline 9 & Govek & Oğlakçı & 7 & - & 7 \\
\hline
\end{tabular}


17. Yüzyıl Ortalarında Varto (Yerleşim, Nüfus, Vergi ve Aşiretler)

\begin{tabular}{|c|c|c|c|c|c|c|}
\hline 10 & Alagöz & Yukarı ve Aşağı Alagöz & 4 & - & 4 & \\
\hline 11 & $\begin{array}{l}\text { Karagöl nâm-1 diğer } \\
\text { Bestam Gölü }\end{array}$ & - & 6 & - & 5 & \\
\hline 12 & Diğer Karagöl & - & 3 & - & 4 & \\
\hline 13 & Alibijan & Alibici (Mezra) & 18 & - & 23 & \\
\hline 14 & Karakurd (Karkarud) & Sazlica & - & 14 & 14 & \\
\hline 15 & Karamişe & Karameşe & 12 & - & 15 & \\
\hline 16 & Habiban & Haksever & 8 & - & 8 & \\
\hline 17 & Bazan & Teknedüzü & 4 & - & 9 & \\
\hline 18 & Sultanşe & Ocaklı & 2 & - & 3 & \\
\hline 19 & Rindali & Buzlugöze & 3 & - & 3 & 벟 \\
\hline 20 & Kal'acık & Kalecik & 4 & 1 & 5 & $\begin{array}{l}\text { HISTORY } \\
\text { STUDIES }\end{array}$ \\
\hline 21 & $\begin{array}{l}\text { Dodan nâm-1 diğer } \\
\text { Hüseyin Şahab }\end{array}$ & İlbey & 16 & - & 18 & 1150 \\
\hline 22 & $\begin{array}{l}\text { Bazgan nâm-1 diğer İlyas } \\
\text { Köy }\end{array}$ & Kaynarca & 10 & - & 10 & $\begin{array}{c}\text { Volume } 12 \\
\text { Issue } 3 \\
\text { June } \\
2020\end{array}$ \\
\hline 23 & $\begin{array}{l}\text { Devletşah nâm-1 diğer } \\
\text { Diyadin }\end{array}$ & Ölçekli & 14 & - & 14 & \\
\hline 24 & Güllüce & Çayçatı, Güllüce (Mezra) & 4 & - & 5 & \\
\hline 25 & Karagiviç & Özkaynak & 5 & - & 5 & \\
\hline 26 & Çorsan & Yeşildal & 2 & - & 9 & \\
\hline 27 & Okçu Cafer ${ }^{35}$ & - & 13 & - & 13 & \\
\hline 28 & $\begin{array}{l}\text { Alikaç ve Kızılmescid } \\
\text { Mezrası }\end{array}$ & Aligedik, Mescitli & 13 & - & 12 & \\
\hline 29 & K1z1lmescid & Kızılmescitli & 7 & - & 8 & \\
\hline 30 & Yilanlı & Y1lanlı & 4 & - & 4 & \\
\hline 31 & Armudlu-1 Kebir & Armutkaşı & 13 & - & 19 & \\
\hline
\end{tabular}

${ }^{35}$ Tahrir emininin izlediği yola bakılırsa Okçu Cafer, Kızılmescid ve Alikaç köyleri Üstükran bölgesinde Bingöl Dağları'nın güney yamacında olmalıdır. 
Murat Alanoğlu

\begin{tabular}{|l|l|l|l|l|l|}
\hline 32 & Armudlu-1 Sağir & Armutkaşı & 11 & - & 11 \\
$\mathbf{3 3}$ & $\begin{array}{l}\text { Üstükran nam-1 diğer } \\
\text { Karatokaç }\end{array}$ & Çaylar & 7 & - & 8 \\
$\mathbf{3 4}$ & $\begin{array}{l}\text { Armudlu mezra-i } \\
\text { Karatokaç }\end{array}$ & Üçbulak & 3 & - & 9 \\
$\mathbf{3 5}$ & $\begin{array}{l}\text { Haşhaş } \\
\text { Toplam Hane Sayısı }\end{array}$ & 3 & - & 3 \\
\hline
\end{tabular}

Grafik-1: 1642 'de Varto Köyleri ve Nüfusun Dini Dağılımı
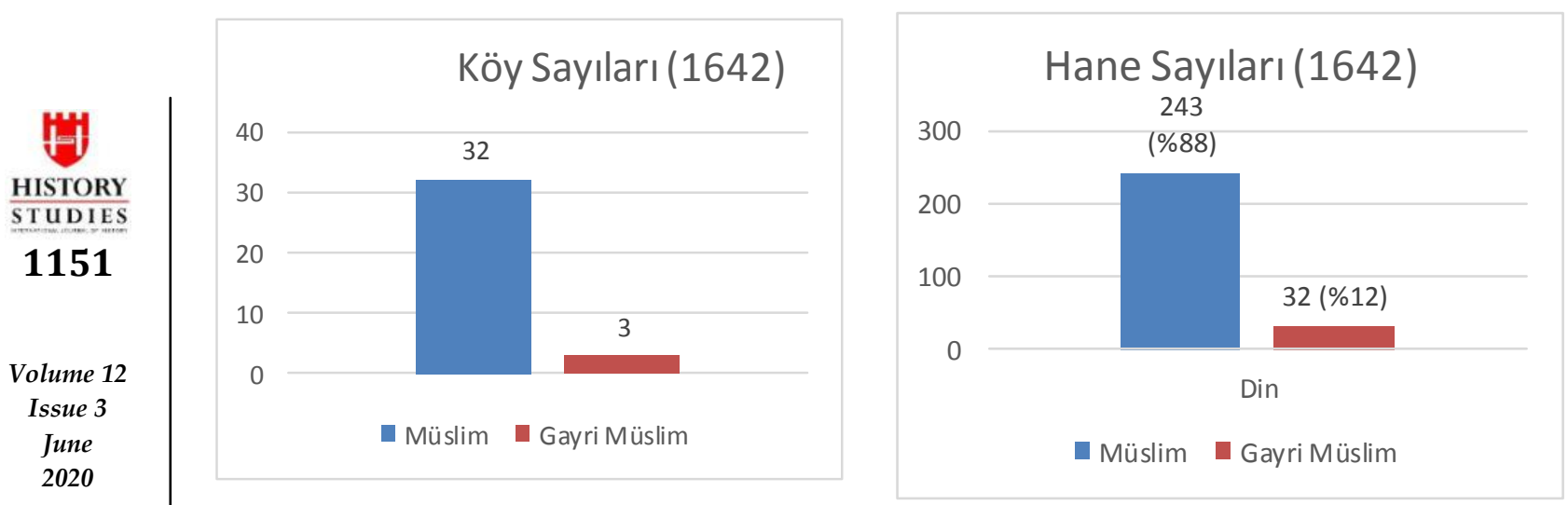

Defterde kayda geçenler sadece hane sahibi evli erkeklerdi. Bu durumda bir hanenin kaç kişiden meydana geldiği sorusu akla gelebilir. Bu konu çok tartışmalı olmakla birlikte Osmanlı demografisini çalışan kimi araştırmacılar bir hanenin, hane sahibinin eşi ve çocukları ile birlikte 5 veya 7 kişiden oluştuğu tahmininde bulunmuşlardır. ${ }^{36} \mathrm{Bu}$ rakam bulunulan coğrafya, şehir ve toplumsal tabakaya göre değişiklik göstermekle birlikte Ö. Lütfi Barkan'ın önerdiği “1 Hane: 5 kişi” formülü genel kabul görmüştür. ${ }^{37}$ Yine de bu hesaplamanın kesin sonuç vermediği, ancak genel bir görüntü veya tahmin olduğu akıldan çıkarılmamalıdır. ${ }^{38} \mathrm{Bu}$ hesaba göre 1642 yılında Varto'da 243 X 5:1.215 Müslüman ve 32 X 5: 160 gayrimüslim olmak üzere toplam 1.367 kişi yaşamaktayd.

1643 tarihli icmal avârız defterinde ise bazı köylerde nüfusun arttığı görülmektedir. Sadece köy isimleri, köydeki hane miktarı ve buradan toplanan avârızhâne vergisinin kaydedildiği

\footnotetext{
36 Rifat Özdemir, "Avârız ve Gerçek-Hâne Sayılarının Demografik Tahminlerde Kullanılması Üzerine Bazı Bilgiler”, X. Türk Tarih Kongresi, Ankara, 22-26 Eylül 1986, Kongreye Sunulan Bildiriler, C. IV, Ankara 1993, s, 1604.

${ }^{37}$ Bkz. Ö. Lütfi Barkan, "Tarihî Demografî̀ Araştırmaları ve Osmanlı Tarihi”, Türkiyat Mecmuası, C. X (19511953), s. 1-24.

${ }^{38}$ Nejat Göyünç, "Hâne Deyimi Hakkında”, Tarih Dergisi, sayı 32 (1979), s. 331-348.
}

\section{History Studies}


defterde bir önceki yıla göre köy sayısı aynı kalmakla beraber hane sayısında 58 artış meydana gelmiştir. Yani bir yılda Varto nahiyesindeki hane sayısı 275'ten 333 çıkmışı. Muhtemelen ilk sayımda bazı haneler eksik yazılmıştı veya hane mensupları sayımdan kaçmışlardı. Daha sonra bunlar tekrar gözden geçirilmiş ve güncel rakamlar kaydedilmiş olmalıdır. ${ }^{39}$ Gayrimüslimlerin yaşadığı Satışeyh köyünde altı hanelik bir artış görülmektedir. Diğer Ermeni köylerinde rakam aynı kaldığından toplamda altı yeni Ermeni hanenin eklendiği anlaşılmaktadır. Dolayısıyla yeni eklenen hanelerin 52'si Müslüman nüfusa aitti. Hane sayısı artan köyler olmakla birlikte hane sayısı düşen köye de rastlanmaktadır. Genel itibariyle hane sayısındaki artışa rağmen vergi miktarını gösteren avârızhâne sayısında fazla bir artış olmamıştı. 1643 tarihli icmal defterde ise Varto'nun nüfusu 58 hane artı̧ ile 333'e ulaşmıştı. Yeni eklenenlerle birlikte 1643'te Varto nüfusu Barkan'ın hesaplama yöntemiyle 333 hanenin beş ile çarpımından 1.665 kişiye çıkmıştı.

1645 ve 1650 tarihli icmal defterlerde Varto'daki köy sayılarında bazı değişikliklerin olduğu göze çarpmaktadır. Ayrıca köylerin defterde sıralanışında da 1642 tarihli deftere göre kimi farklılıklar mevcuttur. 1645 tahririnde Varto'daki köy sayısı 39'a çıkmış, bu rakam 1650 tarihli sayımda ise 38'e inmiştir. 1642 tarihli mufassal defterde Hınıs ile Muş arasında derbent/menzilgâh olduğu belirtilen Üçbudak köyü 1645 ve 1650 sayımına ait kayıtlarda mevcut değildir. İnak köyü ise 1642 ve 1645 'te mevcut iken, 1650 kaydında yer almamaktadır. 1642'de olmayıp 1645 ve 1650 tahririnde Beykomu, Pirahmed, Hanasır, Hasidan ve Kaleköy ma $a^{40}$ Aner adında beş yeni köy kaydedilmiştir. Köy sayıları artmış olmakla birlikte bu kayıtlarda köylerde yaşayan gerçek hane sahipleri belirtilmemiş, sadece köy adı ve buradan alınan avârız vergisi miktarı yazılmıştır. Aşağıdaki tabloda köy sayıları ve yeni eklenen köyler görülmektedir.

Tablo-2: 1642, 1643, 1645 ve 1650 Tarihli Avârız Defterlerine Göre Varto Nahiyesinde Köy Sayıları

\begin{tabular}{|c|c|c|c|}
\hline & Köy Adı (1642-1643) & 1645 & 1650 \\
\hline 1 & Hinzori & Hinzori & Hinzori \\
\hline 2 & Üçbudak & - & - \\
\hline 3 & İnak & İnak & - \\
\hline 4 & Kirs & Kirs & Kirs \\
\hline 5 & Karçıgay & Karçıgay & Karçıgay \\
\hline 6 & Satışeyh & Satışeyh & Satışeyh \\
\hline 7 & Gümgüm & Gümgüm & Gümgüm \\
\hline 8 & Gestmerd & Gestmerd & Gestmerd \\
\hline
\end{tabular}


Murat Alanoğlu

\begin{tabular}{|c|c|c|c|}
\hline 9 & Govek & Govek & Govek \\
\hline 10 & Alagöz & Alagöz & Alagöz \\
\hline 11 & $\begin{array}{l}\text { Karagöl nâm-1 diğer } \\
\text { Bestam Gölü }\end{array}$ & $\begin{array}{l}\text { Karagöl nâm-1 diğer } \\
\text { Bestam Köyü }\end{array}$ & Karagöl nâm-1 diğer Bestam Köyü \\
\hline 12 & Diğer Karagöl & Diğer Karagöl & Diğer Karagöl \\
\hline 13 & Alibijan & Alibican & Alibican \\
\hline 14 & Karakurd & Karakurd & Karakurdan \\
\hline 15 & Karamişe & Karameşe & Karameşe \\
\hline 16 & Habiban & Habiban & Habiban \\
\hline 17 & Bazan & Bazan & Bazan \\
\hline 18 & Sultanşeh & Sultanşeh & Sultanşe \\
\hline 19 & Rindali & Rindali & Rindali \\
\hline 20 & Kal'acık & Kal'acık & Kal'acık \\
\hline 21 & $\begin{array}{l}\text { Dodan nâm-1 diğer } \\
\text { Hüseyin Şahab }\end{array}$ & $\begin{array}{l}\text { Dodan nâm-1 diğer } \\
\text { Hüseyin Şahab }\end{array}$ & Dodan nâm-1 diğer Hüseyin Şahab \\
\hline 22 & $\begin{array}{l}\text { Bazgan nâm-1 diğer İlyas } \\
\text { Köy }\end{array}$ & $\begin{array}{l}\text { Bazgan nâm-1 diğer } \\
\text { İlyas Köy }\end{array}$ & Bazigan nâm-1 diğer İlyas Köy \\
\hline 23 & $\begin{array}{l}\text { Devletşah nâm-1 diğer } \\
\text { Diyadin }\end{array}$ & $\begin{array}{l}\text { Devletşah nâm-1 diğer } \\
\text { Diyadin }\end{array}$ & Devletşah nâm-1 diğer Diyadin \\
\hline 24 & Güllüce & Güllüce & Güllüce \\
\hline 25 & Karakoç & Karakoç & Karakoç \\
\hline 26 & Çorsan & Çorsan & Çorsan \\
\hline 27 & Okçu Cafer & Okçu Cafer & Okçu Cafer \\
\hline 28 & $\begin{array}{l}\text { Alikaç ve Kızılmescid } \\
\text { Mezrası }\end{array}$ & $\begin{array}{l}\text { Alikaç ve Kızılmescid } \\
\text { Mezrası }\end{array}$ & Alikaç ve Kızılmescid Mezrası \\
\hline 29 & Kizılmescid & Kiz1lmescid & Kiz1lmescid \\
\hline 30 & Y 1lanlı & Y 1 lanlı & Y 1lanlı \\
\hline 31 & Armudlu-1 Kebir & Armudlu-1 Kebir & Armudlu-1 Kebir \\
\hline
\end{tabular}


17. Yüzyıl Ortalarında Varto (Yerleşim, Nüfus, Vergi ve Aşiretler)

\begin{tabular}{|l|l|l|l|}
\hline 32 & Armudlu-1 Sağir & Armudlu-1 Sağir & Armudlu-1 Sağir \\
\hline $\mathbf{3 3}$ & $\begin{array}{l}\text { Üstükran nam-1 diğer } \\
\text { Karatokaç }\end{array}$ & $\begin{array}{l}\text { Üstükran nam-1 diğer } \\
\text { Karatokaç }\end{array}$ & Üstükran nam-1 diğer Karatokaç \\
\hline $\mathbf{3 4}$ & $\begin{array}{l}\text { Armudlu mezra-i } \\
\text { Karatokaç }\end{array}$ & $\begin{array}{l}\text { Armudlu mezra-i } \\
\text { Karatokaç }\end{array}$ & Armudlu mezra-i Karatokaç \\
\hline $\mathbf{3 5}$ & Haşhaş & Haşhaş & Haşhaş \\
\hline $\mathbf{3 6}$ & - & Beykomu & Beykomu \\
\hline $\mathbf{3 7}$ & - & Pirahmed & Pirahmed \\
\hline $\mathbf{3 8}$ & - & Hanasir & Hanasır \\
\hline $\mathbf{3 9}$ & - & Hasidan & Hasidan \\
\hline $\mathbf{4 0}$ & - & Kaleköy ma‘a Aner & Kaleköy ma‘a Aner \\
\hline Toplam: & $\mathbf{3 5}$ & $\mathbf{3 9}$ & $\mathbf{3 8}$ \\
\hline
\end{tabular}

Köylerin nicel yapısına dair bu bilgilerden sonra Varto'nun 16. ve 17. yüzyıllardaki nüfusunun karşılaştırmasına geçilebilir. 16. yüzyıla ait $1556^{41}$ ve $1568^{42}$ tarihli defterler eksiksiz olmaları ve ayrıntılı bilgiler içermemeleri sebebiyle buradaki verileri esas almak durumunda kalınmıştır. Bu defterlerdeki köy sayıları aşağıda da belirtildiği üzere 90 civarındaydı. Fakat bu sayı aynı zamanda Handırıs ve Bulanık nahiyeleri dâhil edilmişs şekilde ulaşılan sayıydı. 1642-1650 yıllarına ait sayımlarda ise sadece Varto nahiyesi ele alındığından köy sayıları 35-39 arasında seyretmişti. Dolayısıyla 1640'lı yıllara ait defterde isimleri geçen köylerin nüfus durumunu aşağıdaki tabloda vererek karşılaştırma imkânı elde edilmiştir. Fakat sadece 1642 ve 1643 tarihli defterlerde köylerdeki hane sayısı, 1645 ve 1650'de ise yalnız köy adı ve avârızhâne miktarı verilmiştir. Bu yönüyle karşılaştırma imkânı veren tek kaynak 1642 tarihli mufassal ve bu defterin 1643 tarihli icmal kaydıdır.

\footnotetext{
${ }^{41}$ BOA, TT. $d$, nr. 294, s. 63-91

${ }^{42}$ BOA, TT. $d$, nr. 70, s. 26-41.
} 
Grafik-2: 1556-1643 Yılları Arasında Varto'da Nüfus Miktarları ve Değişim Oranları ${ }^{43}$

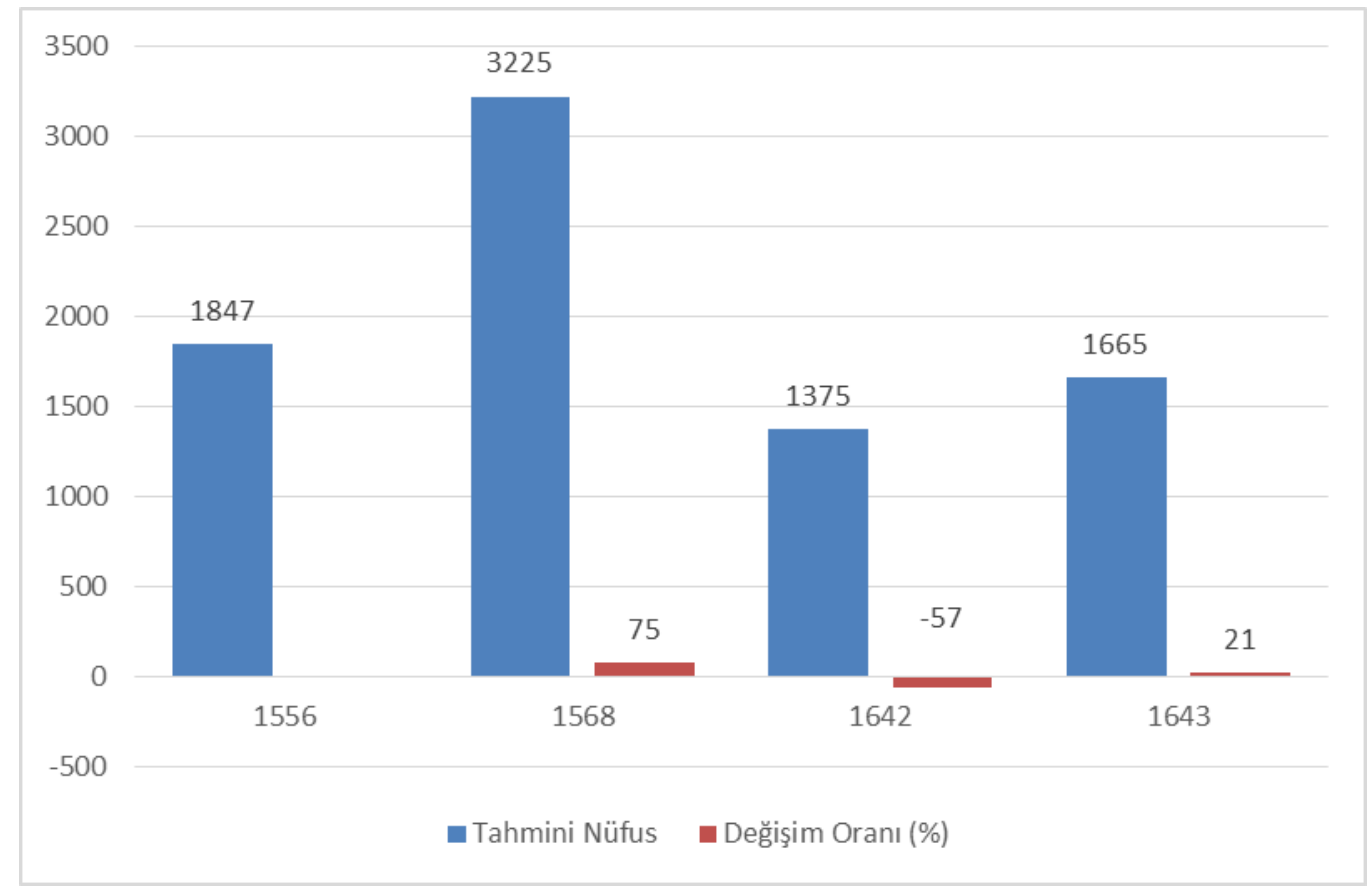

Volume 12

İki yüzyıla ait verilerin mukayese edilmesiyle hem köylerin dinî yapısı hem de nüfus toplamını verecek hane sayılarıyla, 16. ve 17. yüzyıllara ait genel bir karşılaştırma imkânı elde edilecektir. Aynı zamanda 1556 ile 1568 yılları arsındaki nüfus artışı görülmüş, daha sonra 17. yüzyılın ortalarında nüfusun dramatik şekilde düştügü ve önceki yüzyıla göre Varto'nun nüfusunun yarısını kaybettiği tespitinde bulunulmuştur. Zira 1556 yılında Varto'da seçilen 37 köyde 237 Müslim hane, 110 gayrimüslim hane, 74 mücerred (bekâr), 38 görevli ve göçmen yaşamaktaydı. Haneler beş ile çarpılıp mücerredler eklendiğinde toplam nüfus 1.847 kişiydi. Söz konusu köylerde bir sonraki tahririn yapıldığ1 1568 'de ise nüfusun bir hayli arttığ görülmektedir. 1568'de Varto'da 395 Müslim hane, 186 gayrimüslim hane, 281 mücerred, dört görevli, 35 göçmenin yaşadığı kayda geçmişti. Yine aynı şekilde muhtemel hesaplamayla Varto'da 3.225 kişinin yaşadığı söylenebilir. Böylece nüfusun iki kata yakın arttığ1 görülmektedir. 17. yüzyıla gelindiğinde Varto'da kayda geçen köy sayısı üçte bir nispetindeydi. Zira 16. yüzyı1 ikinci yarısında 90'1 aşan köy sayısı 30'lara kadar düşmüştü. Muhtemelen bu köyler çeşitli sebeplerle boşalmıştı. Boşalmayan köylerde ise nüfus dramatik şekilde düşmüştü. $\mathrm{Bu}$ gelişmenin temel sebepleri arasında Celali isyanları, Abaza Mehmed Paşa isyanı, ağır vergiler, veba ve İran harpleri sayılabilir. 1642'de Varto'da kaydedilen 35 köyde 243 Müslüman ve 32 Ermeni hane olmak üzere 275 hane yaşamaktaydı. Bu hanelerdeki kadın ve çocuk sayısını bulmak için hane sayısı beş ile çarpıldığında bulunan rakam 1.375 olmaktadır. 1643 tarihli icmalde ise köy sayısı aynı kalmakla birlikte 58 yeni hane eklenmiştir. Yeni eklenenlerle birlikte Varto'da 333 hanede 1.665 kişinin yaşadığı söylenebilir. Netice olarak 17.

${ }^{43}$ Bu miktarlar 1642 'de kayda geçen 35 köyün, 16. yüzyıldaki verilerinin hesaplanmasıyla elde edilmiştir. Varto'nun 16. yüzyıldaki diğer köyleri eklendiğinde 1556 ve 1568 nüfusu daha fazla çıkacaktır. 
yüzyılda Varto'da çok fazla köyün boşaldığı veya kayda geçmediği, kayda geçen köylerde ise nüfusun aşırı şekilde azaldığı sonucuna ulaşılmaktadır. Nüfusu en fazla azalan köyler ise Ermenilere aittir. Örneğin sadece Ermenilerin ikamet ettiği Gümgüm köyünde 1556'da 24 hane, 1568'de 41 hane Ermeni yaşarken 1642 ve 1643'te yalnızca dört hane Ermeni'nin ikamet ettiği görülmektedir. Bu rakam açık bir şekilde nüfusun on kat düştüğünü göstermektedir. Yine Rindali köyünde 1556'da 38 hane, 1568'de 47 hane Ermeni yaşarken 1642'ye gelindiğinde sadece üç hane Ermeni kalmıştı. Burada da nüfusun on kattan daha fazla azaldığ 1 görülmektedir. Nüfusu tamamen yok olmuş köyler de bulunmaktaydı. Örneğin Kalekendi köyünde 1556 'da 31 hane yerleşik ile 16 hane göçmen gayrimüslim, 1568'de 48 yerleşik, 12 göçmen gayrimüslim hane yaşamaktaydı. Oysa 1642'deki kayıtta ise Kalekendi köyünde yaşam izine rastlanmamaktadır. Keza aynı bölgede bulunan Aner köyünde ise 1556'da 20 gayrimüslim, 1568'de 35 gayrimüslim hane yaşarken 1642'e gelindiğinde köy tamamen boşalmıştı. 1645 ve 1650 kayıtlarında tekrar kayda geçen Aner, Kaleköy ile birlikte yazılmıştı. Kesin hane sayısı verilmeyen her iki köyün avârızhâne miktarından yaklaşık 20 hanenin yaşadığı sonucuna ulaşılabilmektedir. Keza İlyasköy ya da diğer adıyla Bazgan'da 1568 yılında 20 gayrimüslim kaydedilmiştir. Ancak 1642'de köyde gayrimüslim nüfusa tesadüf edilmemiş ve sadece 10 Müslim hane kayda geçmiştir. Peki, gayrimüslim köylerinde durum izah edilen şekilde iken Müslüman köylerinde nüfusun seyri ne durumdaydı? Mesela en büyük köylerden biri olan Hınzori'de 1556 'da 14 hane ve beş bekâr Müslüman, 1568'de 46 hane ve 59 bekâr Müslüman yaşarken 1642 'de Müslüman hane sayısı 21'e düşmüş, bir sonraki tahrirde ise 28 haneye çıkmıştı. Bu rakam bize Hınzori köyündeki Müslüman nüfusun yarıdan fazla azaldığını göstermektedir. 16. yüzyılın kalabalık köylerinden Satışeyh'te 1556'da sekiz hane ve beş bekâr, 1568 'de ise 25 hane ve sekiz bekâr Müslüman yazılmışken 1642'de 13 Ermeni hane, 1643'de 19 hane kayda geçmişti. Burada Müslüman nüfusun yerini Ermeniler almıştı. Bir diğer büyük köy Karatokaç'ta 1556 'da 39 hane ve sekiz bekâr, 1568'de 20 hane ve 13 bekâr Müslüman yaşarken, 1642'e gelindiğinde köyde sadece yedi hane Müslüman yazılmıştır. Aşağıdaki tabloda nüfusun yıllara ve köylere göre dağılımı verilmiş ancak burada verilen toplam nüfus miktarları kesin olmayıp hanelerin beş ile çarpımından elde edilen yaklaşık değerlerdir.

Tablo-3: 16 ve 17. Yüzyılda Varto'da Nüfus

\begin{tabular}{|c|c|c|c|c|c|c|c|c|c|}
\hline \multicolumn{10}{|c|}{ Tablo-3: 16 ve 17. Yüzy1lda Varto'da Nüfus } \\
\hline \multirow{2}{*}{\multicolumn{2}{|c|}{ Köy Adı }} & \multicolumn{3}{|c|}{1556} & \multicolumn{3}{|c|}{1568} & \multirow{2}{*}{$\begin{array}{r}1642 \\
\mathrm{M} / \mathrm{E}^{44}\end{array}$} & \multirow{2}{*}{$\begin{array}{r}1643 \\
\text { Hane }\end{array}$} \\
\hline & & Müslim & $\begin{array}{l}\text { Gayri } \\
\text { müslim }\end{array}$ & $\begin{array}{l}\text { Görevli/ } \\
\text { Muaf }\end{array}$ & Müslim & $\begin{array}{l}\text { Gayri } \\
\text { müslim }\end{array}$ & $\begin{array}{l}\text { Görevli/ } \\
\text { Muaf }\end{array}$ & & \\
\hline 1 & Hinzori & $14 \mathrm{H}^{45}+5 \mathrm{M}$ & - & - & $46 \mathrm{H}+59 \mathrm{M}$ & - & - & $21 \mathrm{M}$ & 28 \\
\hline 2 & $\begin{array}{l}\text { Alagöz-i } \\
\text { Büzürk }\end{array}$ & $3+2$ & - & - & $11+13$ & - & - & $4 \mathrm{M}$ & 4 \\
\hline 3 & Kirs & $3+2$ & - & - & 9 & - & - & $2 \mathrm{M}$ & 9 \\
\hline
\end{tabular}

\footnotetext{
${ }^{44} \mathrm{M}$ : Müslüman, E: Ermeni

${ }^{45}$ H/Hane: Evli erkek ve ailesi, M/Mücerred: Bekâr erkek
} 
Murat Alanoğlu

\begin{tabular}{|c|c|c|c|c|c|c|c|c|c|c|}
\hline & 4 & Kalecik & $9+1$ & - & - & $7+3$ & - & - & $4 \mathrm{M}+1 \mathrm{E}$ & 5 \\
\hline & 5 & Devletşah & $10+4$ & - & - & $24+15$ & - & - & $14 \mathrm{M}$ & 14 \\
\hline & 6 & $\begin{array}{l}\text { Armudlu } \\
\text {-i Kebir }\end{array}$ & $9+10$ & - & 1 İmam & $18+20$ & - & - & $13 \mathrm{M}$ & 19 \\
\hline & 7 & Okcucafer & $12+4$ & - & 1 İmam & $21+7$ & - & - & $13 \mathrm{M}$ & 13 \\
\hline & 8 & $\begin{array}{l}\text { Armudlu } \\
\text {-i Küçük }\end{array}$ & $4+3$ & - & - & $10+10$ & - & - & $11 \mathrm{M}$ & 11 \\
\hline & 9 & $\begin{array}{l}\text { İnebey/ } \\
\text { İnak }\end{array}$ & 2 & - & - & - & - & - & $6 \mathrm{M}$ & 6 \\
\hline & 10 & $\begin{array}{l}\text { S(Z)at1- } \\
\text { şeyh }\end{array}$ & $8+3$ & - & - & $25+8$ & - & - & $13 \mathrm{E}$ & 19 \\
\hline & 11 & Üçbudak & $16+2$ & - & $\begin{array}{l}3 \\
\text { Sipahizade }\end{array}$ & $20+16$ & - & - & $9 \mathrm{M}$ & 10 \\
\hline 허 & 12 & $\begin{array}{l}\text { Alagöz-i } \\
\text { Küçük }\end{array}$ & $6+1$ & - & - & $13+3$ & - & - & $4 \mathrm{M}$ & 4 \\
\hline $\begin{array}{l}\text { HISTORY } \\
\text { STUDIES }\end{array}$ & 13 & Alikaç & 1 & - & 3 & - & - & - & $13 \mathrm{M}$ & 12 \\
\hline & 14 & Sultanşe & $1+2$ & - & - & 5 & - & - & $2 \mathrm{M}$ & 3 \\
\hline Volume 12 & 15 & Güllüce & $5+1$ & - & - & $11+3$ & - & - & $4 \mathrm{M}$ & 5 \\
\hline June & 16 & Harik & 4 & - & - & 2 & 4 & - & - & - \\
\hline & 17 & Karatokac & $39+8$ & - & $\begin{array}{l}5 \\
\text { Sipahizade }\end{array}$ & $20+13$ & - & - & $7 \mathrm{M}$ & 9 \\
\hline & 18 & Çorsan & 5 & - & - & $12+3$ & - & - & $2 \mathrm{M}$ & 9 \\
\hline & 19 & $\begin{array}{l}\text { Kizil- } \\
\text { mescid }\end{array}$ & 5 & - & - & $17+9$ & - & - & $7 \mathrm{M}$ & 8 \\
\hline & 20 & Yilanlu & 8 & - & 1 İmam & $24+19$ & - & - & $4 \mathrm{M}$ & 4 \\
\hline & 21 & Rindali & - & 36 & 2 Birunî & - & 43 & $\begin{array}{l}14 \\
\text { Birunî̀ }^{46} \text {, } \\
2 \text { Keşiş }\end{array}$ & $3 \mathrm{M}$ & 3 \\
\hline & 22 & $\begin{array}{l}\text { Kaleken- } \\
\text { di }\end{array}$ & - & 31 & 16 Birûnî & - & 48 & 12 Birunî & - & - \\
\hline & 23 & Aner & $47+12$ & 20 & 2 Birunî & - & 35 & 3 Birunî & - & - \\
\hline & 24 & $\begin{array}{l}\text { İlyas/ } \\
\text { Bazgan }\end{array}$ & $9+3$ & - & - & $18+19$ & 20 & - & $10 \mathrm{M}$ & 10 \\
\hline & 25 & Gümgüm & - & 20 & 4 Birûnî & - & 36 & 5 Birunî & $4 \mathrm{E}$ & 4 \\
\hline
\end{tabular}

\footnotetext{
${ }^{46}$ Birunî: Dişardan göçle gelen kimseler
} 
17. Yüzyıl Ortalarında Varto (Yerleşim, Nüfus, Vergi ve Aşiretler)

\begin{tabular}{|c|c|c|c|c|c|c|c|c|c|}
\hline 26 & $\begin{array}{l}\text { Karagiviç/ } \\
\text { Karçı̆gay }\end{array}$ & $4+3$ & - & - & $5+1$ & - & 1 Birunî & $5 \mathrm{M}$ & 5 \\
\hline 27 & Pirahmed & $6+3$ & 3 & & $2+1$ & - & $1 \mathrm{imam}$ & - & - \\
\hline 28 & $\begin{array}{l}\text { Hüseyin- } \\
\text { şihab/ } \\
\text { Dodan }\end{array}$ & - & - & - & $22+19$ & - & - & $16 \mathrm{M}$ & 18 \\
\hline 29 & Bazan & - & - & - & $11+5$ & - & - & $4 \mathrm{M}$ & 9 \\
\hline 30 & $\begin{array}{l}\text { Alibic(j) } \\
\text { an }\end{array}$ & $7+5$ & - & - & $9+9$ & - & - & $18 \mathrm{M}$ & 23 \\
\hline 31 & Haşhaş & - & - & - & $2+4$ & - & - & $3 \mathrm{M}$ & 3 \\
\hline 32 & Karamişe & - & - & - & $31+22$ & - & 1 imam & $12 \mathrm{M}$ & 15 \\
\hline 33 & Gestmerd & Mezra & - & - & - & - & - & $4 \mathrm{M}$ & 4 \\
\hline 34 & Govek & - & - & - & - & - & - & $7 \mathrm{M}$ & 7 \\
\hline 35 & Karagöl & - & - & - & Mezra & & & $6 \mathrm{M}$ & 5 \\
\hline 36 & Karakurd & - & - & - & - & - & - & $14 \mathrm{E}$ & 14 \\
\hline 37 & Habiban & Mezra & & & Mezra & & & $8 \mathrm{M}$ & 8 \\
\hline \multicolumn{2}{|c|}{ Toplam Nüfus } & \multicolumn{3}{|c|}{$\begin{array}{l}237 \text { Müslim Hane, } 110 \text { Gayrimüslim } \\
\text { hane, } 74 \text { Mücerred, } 38 \text { Görevli ve } \\
\text { Göçmen } \\
\text { 237+110: 352 X 5: } \\
\mathbf{1 . 7 3 5 + 7 4 + 3 8 : 1 . 8 4 7}\end{array}$} & \multicolumn{3}{|c|}{$\begin{array}{l}395 \text { Müslim Hane, } 186 \text { Gayrimüslim } \\
\text { Hane, } 281 \text { Mücerred, } 4 \text { Görevli, } 35 \\
\text { Göçmen } \\
\text { 395+186: 581 X 5: 2.905+281+39: } \\
\mathbf{3 . 2 2 5}\end{array}$} & $\begin{array}{l}275 \\
\text { Hane X } \\
5: \\
1.375\end{array}$ & $\begin{array}{l}333 \\
\text { Hane } \\
\text { X 5: } \\
1.665\end{array}$ \\
\hline
\end{tabular}

Volume 12

1642 'de Varto ile çevresindeki yerleşimlerin nüfusunu karşllaştırmak üzere Erzurum'un diğer kaza ve nahiyelerine bakmak yerinde olacaktır. Aynı tarihte Kızuçan (Pülümür) kazasında 29 köyde yaşayan 202'si Müslim ve 158'i gayrimüslim hâne olmak toplam 360 hâne kayıtlıydı. $^{47} \mathrm{Bu}$ hânelerin tahmini nüfusu hesaplandığında 1.010'u Müslüman, 790'1 gayrimüslim olmak üzere toplam 1.800 rakamı ortaya çıkmaktadır. Kızuçan ile Varto arasında yer alan Kiğı kazasında 145 köyde 1330 Müslim ve 399 gayrimüslim olmak üzere toplam 1.729 hâne mevcuttu ve tahmini nüfusu 12.103 'e tekabül etmekteydi. ${ }^{48}$ Varto'ya çok uzak olmayan bir bölgede bulunan Tercan kazası da Tercan-1 Ulyâ ve Tercan-1 Süfla olmak üzere ikiye ayrılmıştı ve 175 köyde 5.813 nefer bulunmaktaydı. ${ }^{49}$ Varto'nun hemen bitişiğinde yer alan Bulanık nahiyesinde 14 köyün meskûn olduğu görülmektedir. Bu 14 köydeki hane sayısı dördü gayrimüslim olmak üzere toplamda 180'di. Hane hesabına göre Bulanık’ta 180 X 5: 900

\footnotetext{
${ }^{47}$ Murat Alanoğlu, "1642 Tarihli Avârız Defterine Göre Kızuçan (Pülümür) Kazâsı”, Tarih Okulu Dergisi, sayı XXVIII, Aralık 2016, s. 121.

${ }^{48}$ Nevzat Sağlam, "5152 Nolu ve H. 1052/M. 1642 Tarihli Maliyeden Müdevver Deftere Göre Kiğı ve Köylerinde İskân ve Nüfus”, II. Bingöl Sempozyumu Bildirileri, Yeni Zaman Sahaf: Ankara 2009, s. 307

${ }^{49}$ Selçuk Demir-İbahim E. Çakır, “Tercan Kazası (1591-1642)”, Karadeniz Araştırmaları, sayı 50, Yaz 2016, s. 162.
} 
kişinin yaşadığı tahmin edilebilir. Bulanık'ta nüfusun önemli bir kısmının 45 hanelik Kızılmescid köyünde yaşadığı görülmektedir. ${ }^{50}$

Varto'da kayda geçen hane sahipleri ile babalarının isimleri bölgenin kültürel, dinî ve sosyal yapısı hakkında ipuçları vermektedir. Zira Varto'nun 16. yüzyılda bir süre Pazuki beylerinin idaresinde Şiî Safevilerin etkisinde kaldığı bilinmektedir. Osmanlı idaresinin kurulmasından sonra Safeviler bölgeden çıkarıldığı gibi bölgedeki Pazuki beyleri de önce daha doğudaki Hınıs ve Erciş'e daha sonra İran tarafına geçmek zorunda kaldılar. Dolayısıyla Osmanlı hâkimiyetinin tesisinden sonra Şii nüfusun İran'a kaymasıyla boşalan yerlere Sünnî-Şafiî aşiretlerin yerleştirildiği söylenebilir. ${ }^{51} \mathrm{Bu}$ bağlamda 17 . yüzyıl kayıtlarındaki kişi isimlerine bakıldığında en fazla kullanılan isim 32 kişi ile Ali’ydi. Ali'den sonra en yaygın isimler şunlardı: Mehmed (21), Ömer (19), Hasan (13), Ahmed ve Mustafa (12'şer), Osman ve Veli (11'şer), Halil (8) ve Yusuf (7). Bunların yanı sıra Safevi geleneğinde yaygın şekilde kullanılan isimlere de rastlanmaktaydı. Nitekim Şahverdi ve Şahgeldi isimleri altı kişiye verilmişti. Yine Pir Ahmed, Pir Veli, Şah Veli, Şah Ali, Şah Veled, Şah Kubad, Allahverdi ve Hüdaverdi isimleri Müslüman köylerde karşımıza çıkmaktadır. Bunların dışında gayrimüslimlerin yaşadığı köylerde Ermenice isimler kayda geçmiştir. En fazla kullanılan Ermenice isimler ise Karabet, Bedros, Bogos, Kaspar, Avannis, Kirkor ve Agop'tu.

\section{17. Yüzyılda Varto'da Yerleşim}

17. yüzyıldaki yerleşime geçmeden önce 16. yüzyıldaki durumu izlemek üzere tahrir defterlerindeki köy sayılarını incelemek faydalı olacaktır. Ancak bu şekilde köy sayısı ve yerleşim yerlerindeki değişimi görmek mümkün olabilir. Varto'ya ait ilk kayıtların yer aldığ 1537 tarihli Bitlis icmal defterinde Varto adı geçmemekle birlikte buraya ait birçok köyün kaydedildiği görülmektedir. 1537 sayımına ait ilk verilere göre Varto ve Hındırıs’ta 31 köy ve 11 mezra bulunmaktadır. Kayıtlı köylerden Kalecik ve Karagiviç, mezralardan Körkasım ve Alagöz'ün harap/boş olduğu kayda geçmiştir. ${ }^{52} 1544$ 'te bölgenin yeni bir tahriri yapılmıştır. Bu sayıma göre Varto'da 33 köy ve dört mezra bulunmaktaydı. Ancak kayıtlı köylerden 14'nün boş olduğu (hâlî ani'r-re‘âyâ) kaydı yer almaktadır. 1537'de mezra olarak kaydedilen Dapak, Kapuc1, Körkasım ve Depecik'in 1544'te köy olarak yazıldığı görülmektedir. ${ }^{53}$ Önceki kayıtlardan farklı olarak Varto'nun nahiye başlığıly kaydedildiği ve ayrıntılı verilerin bulunduğu defter 1556 tarihlidir. Buna göre 1556 y1lında Varto'da 93 köy 51 mezra bulunmaktaydı. Bu yerleşim yerlerinden Değnek, Çatmameşhed, Haşhaş, Tono, Kozluviran, Söğütlü, Karacaviran, Ömerköy, Arpaderesi, Akmeşhed, Beyçimeni, Değirmenderesi, Karaviran, Çatviran ve Yoncalu köyleri ile Haramlu Mezrası terk edilmiş/boş durumdayd1. ${ }^{54}$ II. Selim dönemine ait tahrir verilerini içeren 1568 tarihli defterde Varto'da 95 köy ve 54 mezra olmak üzere toplamda 149 yerleşim yeri kayda geçmiştir. Beyyurdu, İnebey, Tono, Beyçimeni, Değirmenderesi, Çatviran ve Yoncalu köyleri 1556 tarihli defterde bulunup 1568 tarihli

\footnotetext{
${ }^{50}$ BOA, MAD. d, nr. 5152, s. 870-876.

${ }^{51} \mathrm{Bu}$ konu sonraki sayfalarda aşiretler kısmında ele alınmıștır..

${ }^{52}$ BOA. TT. $d$, nr. 189 , s. 28-34.

${ }^{53}$ BOA, MAD. $d$, nr. 22171, s. 25-46.

${ }^{54}$ Zülfiye Koçak, “Tapu Tahrir Defterlerine Göre XVI. Yüzyılda Varto Nahiyesi”, Osmanlı Mirası Araştırmaları Dergisi, C. 5, say1 13, Kasım 2018, s. 227.
} 
defterde yer almazken; Kaşdere, Ağcapınar, Ağçapınarviranı, Kızılkaya, Devriviranı, Seydibeyyurdu, Abaderesi, Mescidlü ve Dirik köylerine 1568 yılında ilk defa rastlanmaktadır. 1556 yllında köy olarak kaydedilen Kalecik-i Diğer, Kepeneklü, Kozluviran, Karakilise, Değnek ve Karaviran 1568 yılında mezra olarak kayıtlıdır. II. Selim dönemine ait 1568 tarihli icmal defterde ise Varto nahiyesine ait 91 köy ve 36 mezra olmak üzere toplam 127 yerleşim yeri kayda geçmiştir. ${ }^{55}$

Tablo-4: 1537-1650 Yılları Arasında Varto Nahiyesi Köy ve Mezra Sayıları

\begin{tabular}{|l|c|c|c|c|c|c|c|}
\hline & $\mathbf{1 5 3 7}$ & $\mathbf{1 5 4 4}$ & $\mathbf{1 5 5 6}$ & $\mathbf{1 5 6 8}$ & $\mathbf{1 6 4 2}$ & $\mathbf{1 6 4 5}$ & $\mathbf{1 6 5 0}$ \\
\hline Köy Sayısı & 31 & 33 & 93 & 95 & 35 & 39 & 38 \\
\hline Mezra Sayısı & 14 & 4 & 51 & 54 & 1 & 2 & 2 \\
\hline $\begin{array}{l}\text { Toplam Yerleşim } \\
\text { Yeri }\end{array}$ & 45 & 37 & 144 & 149 & 36 & 41 & 40 \\
\hline
\end{tabular}

Ayrıntılı veriler sunan 1642 tarihli mufassal avârız tahririnde yer alan köy yerleşimlerine bakıldığında 21 haneli Hınzori, 18 haneli Alibijan, 16 haneli Dodan, 14 haneli Devletşah, 13 haneli Okçu Cafer, Alikaç ve Admudlu-i Kebir köyleri, 12 haneli Karameşe ve 11 haneli Armudlu-1 Sağir köyleri en fazla nüfusu barındıran yerleşim birimleriydi. Diğerleri ise genellikle birkaç hanedan oluşan düşük nüfuslu köylerdi. Zira Köprü, Sultanşeh ve Çorsan köyleri iki haneden oluşmaktaydı. Bu yönüyle Varto bölgesi çok az nüfus barındıran bir bölgeydi ve meskûn köylerde oldukça az kişi yaşamaktaydı.

1642 'de Varto köylerinin coğrafi dağılımına bakıldığında köylerin çoğunlukla bugünkü Varto merkezini oluşturan Gümgüm ve çevresinde yoğunlaştıkları görülmektedir. Nitekim Alagöz, Karameşe, Sultanşeh, Rindali, Habiban, Kalacık, Dodan, Bazgan ve Diyadin, bugünkü Varto'nun batı ve güney batısında yer alan köylerdi. Yerleşim yerlerinin genellikle doğu-batı istikametindeki düzlük alanda ve akarsuların kenarlarında yoğunlaştığı söylenebilir. Günümüz Varto'sunun doğusunda ise İnak, Hınzori ve Üçbudak köyleri yer almaktaydı. Bu tarihte Varto'nun en büyük köyü olan Hınzori bu bölgede yer almaktaydı. Ayrıca derbent olduğu belirtilen Üçbudak köyü de Muş-Hınıs ulaşımını sağlayan yolun üzerinde bulunmaktaydı. Keza Karagöl ve Kızılmescid köylerinin günümüz Akdoğan (Hamurpet) Gölü'nün yakınında olduğunu söylemek mümkündür. Köy yerleşimlerinin yoğunlaştığı alanlardan biri de Varto'nun kuzeybatısına düşen ve Bingöl Dağları'nın yer aldığı sahada bulunan Üstükran, Çorsan, Haşhaş, Yılanlı, Armudlu-1 Sağir ve Kebir, Bazan ve Gestmerd köyleriydi. Bu köyler daha ziyade Bingöl Dağları'nın yamaçlarındaki yüksek kesimlerdeki yayla alanlarında bulunduklarından oldukça seyrek nüfusluydular.

Cumhuriyet'in ilk yıllarına kadar Varto'nun merkezi olduğu belirtilen Gümgüm köyü, 16. yüzyılda kalabalık bir gayrimüslim yerleşimi iken 1642'de dört hane Ermeni'nin yaşadığı

${ }^{55}$ Zülfiye Koçak, “Tapu Tahrir Defterlerine Göre XVI. Yüzyılda Varto Nahiyesi”, s. 228. 
küçük bir köye dönüşmüştü. Daha sonraki gelişmeler köyün büyümesini ve 19. yüzyılda Varto'nun merkezi konumuna yükselmesini sağlamış olmalıdır.

Yukarıda ayrıntısına değinildiği üzere 1642'de yapılan avârız tahririnden sonra birkaç kez mevcut veriler gözden geçirilmiştir. Nitekim 1645 ve 1650 tahririnde Beykomu, Pirahmed, Hanasır, Hasidan ve Kaleköy ma'a Aner adlarında beş yeni köy bulunmaktadır. Bu köyler Varto'nun doğusunda Bulanık'a yakın kesimde yer alan yerleşimlerdi. Ayrıca bu veriler icmal olarak sadece avârızhâne vergi miktarını içerdiğinden köylerde yaşayan gerçek hane sayısını öğrenmek de mümkün değildir. Ancak yeni eklenen köylerin avârızhâne miktarı çeyrek veya yarım avârızhâneden oluşması nedeniyle oldukça küçük köyler olduğu tahmin edilebilir. Sadece Kaleköy bir buçuk avârızhane vermesi nedeniyle yaklaşık 20 haneye sahip ve diğerlerine nispetle kalabalık bir köy olmalıdır.

Yerleşim yerlerinin isimlerine bakıldığında dört farklı kültür ve adlandırmayla karşılaşılmaktadır. Zira Varto'da Türkçe, Kürtçe-Zazaca ve Ermenice birçok yer adına rastlanmaktadır. Örneğin Devletşah, Armutlu, Yılanlı, Okçu Cafer, Üçbudak, Güllüce, Karameşe, Kızılmescid, Karagöl, Karapınar ve Kalekendi köyleri Türkçe adlandırılmıştır. İnak, Zatışeyh, Keçan, Alengoz, Zorava, Sultanşe, Harik, Çorsan, Rindalı, Bazgan, Dodan, Alibijan, Gestmerd, Govek, Giranlığ ve Habiban adları Zazaca ve Kürtçe olarak adlandırılmış yerlerdi. Varto, Hınzori, Dapak, Zernik, Aner ve Karkarut Ermenice isimlendirilmiştir. ${ }^{56}$

\section{Avârız Vergisinden Muaf Kişiler}

Volume 12

Avârız mükellefi olanlar askerî sayılmayan reâyadır. Askerî olarak nitelendirilenlerin içerisinde, fiilen askerlik hizmeti yapanların yanında ulemâ, sulehâ, sadât, derbentçi, tuzcu, çeltikçi, ortakçı, katrancı, doğancı, vakıf reâyası vs. gibi birçok zümreler dâhildi. Ancak ticaret ile uğraşan askeriler de avârız ödemek zorundayd $1 .{ }^{57}$

1642 avârız kayıtlarına göre Varto'da vergiden muaf tutulan tek köy Üçbudak köyüydü. ${ }^{58}$ Buranın Hınıs ve Muş arasında derbent, ${ }^{59}$ yani gelip geçen yolcuların uğrak noktası ve menzilgâhı olduğundan vergiden muaf tutulduğu kayda geçmişti. Bu köyde biri timar sahibi olmak üzere 10 hane yaşamaktayd1. ${ }^{60}$ Varto'da bir bütün vergiden muaf tutulan köyün yanı sıra bireysel muafiyetler de bulunmaktaydı. Bunlardan biri Alibijan köyünde yaşayan Seyyid Şeyh Hüseyin veled-i Hüdaverdi idi. Bu kişi avârız sayımı yapan muharrire kendisinin $\mathrm{Hz}$. Muhammed'in soyundan olduğunu gösteren şecereyi ibraz etmiş, deftere düşülen bir kayıtla Şeyh Hüseyin'in sâdât-1 kirâmdan ${ }^{61}$ olduğu belirtilmiş ve avârız vergisinden muaf tutulmuştu. ${ }^{62}$ Keza aynı köyde yaşayan Molla Abdurrahman, köyün imamı olan saygıdeğer bir âlim olduğundan avârız vergisi ödememişti. Karamişe köyünde yaşayan Molla Hasan, hem köyün

\footnotetext{
56 Köylerin yeni ve eski adları ile bunların etimolojik kökeni için bkz. Sevan Nişanyan, Adını Unutan Ülke Türkiye'de Adı Değiştirilen Yerler Sözlüğ̈̈, Everest, İstanbul 2010, s. 249-251. Tarafımızca bölgede alan araştırması ve bölge tarihini bilen kişilerle yer adları ve coğrafi mekân üzerine mülakatlar yapılmıştır.

${ }^{57}$ Ö. Lütfi Barkan, “Avârız”, IA , C. 2, İstanbul 1979, s. 15; M. Ali Ünal, "1646 (1056) Tarihli Harput Kazası Avârız Defteri, s. 9.

${ }_{58} \mathrm{Bu}$ köy daha sonraki tarihlerde Derbend adını almış olmalı, günümüzde ise köyün adı Çayönü olarak değişmiştir.

${ }^{59}$ Dar geçit, boğaz.

${ }^{60}$ BOA, MAD. $d$, nr. 5152, s. 877.

${ }^{61} \mathrm{~Hz}$. Muhammed'in soyundan gelen kimselere verilen ad.

${ }^{62}$ BOA, MAD. $d$, nr. 5152, s. 882 .
} 
imamı hem de muallimi olarak görev yapmaktaydı. Ancak muafiyetine dair not olmamakla birlikte, kendisinden avârız talep edilmediğini düşünmek yanlış olmayacaktır. Dodan köyünde ise Molla Abdullah, müderrislik ve muallimlik yapan saygın bir âlim olmasından dolayı muaf kaydedilmişti. Yine Dodan köyünde yaşayan Şahab, fakir olduğu belirtilerek avârızhane hesabına dâhil edilmemişti. ${ }^{63}$ Alikaç köyünden Osman veled-i Şah Berat için "harç verir reayadan değildir" kaydı düşülmüştü. ${ }^{64} \mathrm{Bu}$ kayıtlardan Varto'da mevcut köylerden sadece Karamişe, Dodan ve Alibijan köylerinde görevli imam bulunmaktaydı. Dolayısıyla bu köylerde cami bulunduğu sonucuna varılabilir. Dodan köyünde Molla Abdullah'ın müderris olarak kaydedilmesi ve eğitim verdiğinden bahsedilmesi nedeniyle burada bir medrese veya tekkenin bulunduğunu söylemek de mümkündür.

Varto'nun avârız kayıtlarına bakıldığında İnak köyünde molla unvanı kullanan üç kişi olmakla birlikte bunların imamlık yaptıklarına dair bir kayıt yoktur. Hınzori köyünde Molla Mehmed veled-i Gül Ali, Habiban köyünde de molla unvanı kullanan Süleyman isimli bir kişi yazılmıştı. Bazgan köyünde Molla Abdurrahman veled-i Molla Ömer kaydında hem kendisi hem de babasının unvanını göstermekteydi. Büyük Armudlu köyünden Molla Kılbaş veled-i Kamer kayda geçmişti. Üstükran köyünden Osman oğlu Molla Veli'nin timar tasarruf ettiği belirtilmişti. Haşhaş köyünde Molla Ömer unvanlı birisi kaydedilmişti. Üstükran köyünde ise Molla Alihan veled-i Molla Şems ismi yer almaktaydı. Ancak bu kişilerin imamlık görevi yaptıklarını söylemek zor görünmektedir. Bunun yerine molla unvanlı kişilerin dini eğitim aldıklarından ahali arasında bu şekilde isimlendirildiklerini ifade etmek daha uygun olacaktır. Görevli imam bulunmayan köylerde camii olmadığı ve bunun yerine küçük bir mescidin bulunduğunu düşünmek olasıdır. Bu mescitlerde köyde molla unvanı taşıyan kimselerin namaz kıldırdıkları ihtimalini göz önünde bulundurmak gerekir. Eğer Alevi inancı o günkü Varto'da yaşanıyorduysa imam bulunmayan köylerde camii ve mescit yerine herhangi bir mekânın cemevi olarak kullanıldığını düşünmek daha uygun bir çıkarım olacaktır. Ancak bunu kesin şekilde ifade etmek için elimizde kanıt bulunmamaktadır. Zira defterde hem böylesi bir ibadet mekânından hem de görevlisinden bahsedilmemektedir.

Bazı köylerde şeyh unvanı kullanan kimselerin de olduğu görülmektedir. Bunlar içinde Govek köyünden Şeyh Murad, yine Alagöz köyünden Şeyh Murad, Alibijan köyünden Şeyh Ahmed ve Şeyh Şems, Habiban köyünden Şeyh Mehmed, Dodan köyünden Şeyh İbrahim, Kızılmescid köyünden Şeyh Hüseyin, Üstükran köyünden Şeyh Emir ve Armudlu köyünden Şeyh Emir kayıtlı olanlardı. Buradaki şeyh ifadesinden bunların vazifeli din adamı olduğunu söylemek güçtür. Zira dinî bir vazife icra etmiş olsalardı Alibijan köyünde kayıtlı Seyyid Seyh Hüseyin gibi vergiden muaf tutulurlardı. Oysa şeyh unvanının isimlerinden önce kullanan yukarıdaki kimseler için bir muafiyet tanınmamıştı. Şeyh unvanının yanı sıra bazı isimlerden önce Seyyid ifadesinin kullanıldığı da vakiydi. Fakat bu kimselerin sâdâttan olduğunu söylemek mümkün değildir.

Varto'da askerî olarak nitelendirilen aşiret reisi, imam, şeyh veya seyyid gibi din adamları kayda geçmiş ve bunların vergiden muaf tutuldukları belirtilmişti. Bu cümleden olarak Alibijan

${ }^{63}$ BOA, MAD. $d$, nr. 5152, s. 884 .

${ }^{64}$ BOA, MAD. $d$, nr. 5152, s. 888 . 
köyünde mir-i aşiret ve beyzade olarak üç kişi yazılmıştı, askerlik görevi yapan kimselerin çocuğu olan sipahizâdelerin biri Hınzori ikisi Karamişe'de olmak üzere toplam üç kişiydi. Timar sistemi içinde askerlik görevi yapanlar ise erbab-1 timar adıyla kaydedilmişti. Bunlar dokuz köyde yaşayan toplam 13 kişiydi. En fazla timar görevlisi dört kişi ile Hınzori köyündeydi. Din adamı olarak ibadet ve eğitim-öğretim işlerinden sorumlu olduklarından dolayı muaf olan üçü şeyh ve üçü de imam olan altı kişi kaydedilmişti. Varto'da maddi durumu yetersiz olduğundan dolayı vergi talep edilmeyen tek kişi ise Dodan köyünde yaşayan Şahab'tı. Buna göre Varto'da mukim toplam 275 haneden 26'sı vergiden muaf tutulmuştu. Aşağıdaki tabloda muaf tutulan kimselerin köyleri ve görevleri yer almaktadır.

Tablo-4: 1642'de Varto'da Görevliler ve Vergiden Muaf Olan Kimseler

\begin{tabular}{|c|c|c|c|c|c|c|c|c|}
\hline \multicolumn{2}{|c|}{ Köy Adı } & \multirow{2}{*}{$\begin{array}{l}\text { Mîr-i } \\
\text { aşiret/ } \\
\text { Beyzâde }\end{array}$} & \multirow{2}{*}{$\begin{array}{c}\text { Sipahi- } \\
\text { zâde } \\
\\
\\
1\end{array}$} & \multirow{2}{*}{$\begin{array}{c}\text { Erbâb-ı } \\
\text { Timar } \\
\\
1\end{array}$} & \multirow[t]{2}{*}{$\begin{array}{l}\text { Şeyh/ } \\
\text { Seyyid }\end{array}$} & \multirow[t]{2}{*}{$\begin{array}{c}\text { İmam/ } \\
\text { Muallim }\end{array}$} & \multirow[t]{2}{*}{ Fakir } & \multirow{2}{*}{$\begin{array}{c}\text { Toplam } \\
\\
2 \\
\end{array}$} \\
\hline 1 & Hinzori & & & & & & & \\
\hline 2 & Üçbudak & & & 1 & & & & 1 \\
\hline 3 & Köprü & & & 1 & & & & 1 \\
\hline 4 & Diğer Karagöl & & & 1 & & & & 1 \\
\hline 5 & Alibijan & 3 & & 4 & 1 & 1 & & 9 \\
\hline 6 & Karakurd & & & & & & & \\
\hline 7 & Karamişe & & 2 & & & 1 & & 3 \\
\hline 8 & Sultanşe & & & 1 & & & & 1 \\
\hline 9 & $\begin{array}{l}\text { Dodan nâm-1 } \\
\text { diğer Hüseyin } \\
\text { Şahab }\end{array}$ & & & 2 & & 1 & 1 & 4 \\
\hline 10 & Güllüce & & & & 1 & & & 1 \\
\hline 11 & Çorsan & & & 1 & & & & 1 \\
\hline 12 & Kızılmescid & & & & 1 & & & 1 \\
\hline 13 & Armudlu-1 Sağir & & & & & & & \\
\hline 14 & $\begin{array}{l}\text { Üstükran nam-1 } \\
\text { diğer Karatokaç }\end{array}$ & & & 1 & & & & 1 \\
\hline & Toplam & 3 & 3 & 13 & 3 & 3 & 1 & 26 \\
\hline
\end{tabular}




\section{Toplanan Avârız Vergisi Miktarı}

Avârız mükelleflerinin tespiti hususunda muayyen bir kuralın bulunmadığı görülmektedir. Durumsal değişimler ve coğrafyaya göre 4 ila 50 gerçek hane bir avârızhâneyi oluşturabilmektedir. Bölgelere, halkın gelir durumuna ve sahip olunan gayrimenkule göre değişen oranlarda bu verginin alındığı anlaşılmaktadır. Dolayısıyla bu durum tahriri yapılan bölgedeki halkın ekonomik gücünü de göstermesi bakımından önemlidir. ${ }^{65}$

Varto nahiyesinde her bir köydeki hâne sahibi kişiler yazıldıktan sonra hâsıl başlığı ile o köydeki "avârızhânesi" yazılmıştır. Avârızhâne oranı köyün iktisadi durumuna göre değişiklik arz etmektedir. Varto'da meskûn 275 haneden 26 muaf çıkarılınca 249 hane kalmaktadır. Bu 249 gerçek haneden toplanan 19.25 âvarızhâneye bölündügünde 12,9 rakamına ulaşılmaktadır. Dolayısıyla Varto nahiyesinde yaklaşık 13 gerçek hane bir avârızhâne sayılmıştır.

\begin{tabular}{|c|c|c|c|c|c|}
\hline \multicolumn{6}{|c|}{ Tablo-6: Varto Nahiyesi Avârız-hâne Sayısı } \\
\hline & Köy Adı & $\begin{array}{l}\text { Müslim Gerçek } \\
\text { Hane }\end{array}$ & $\begin{array}{l}\text { Gayrimislim } \\
\text { Gerçek Hane }\end{array}$ & $\begin{array}{l}\text { Avârızhâne } \\
\text { Sayısı (1642) }\end{array}$ & Avârızhâne Sayısı (1643) \\
\hline 1 & Hinzori & 21 & - & 1 & 1 \\
\hline 2 & Üçbudak & 9 & - & Muaf & $0.50^{66}$ \\
\hline 3 & İnak & 6 & - & 0.25 (Çeyrek) & 0.375 \\
\hline 4 & Köprü & 2 & - & 0.25 & 0.25 \\
\hline 5 & Karçıgay & 5 & - & 1 & 1 \\
\hline 6 & Satışeyh & - & 13 & 1.5 & 1.5 \\
\hline 7 & Gümgüm & - & 4 & 0.50 & 0.50 \\
\hline 8 & Gestmerd & 4 & - & 0.25 & 0.25 \\
\hline 9 & Govek & 7 & - & 0.50 & 0.50 \\
\hline 10 & Alagöz & 4 & - & 0.25 & 0.25 \\
\hline 11 & $\begin{array}{l}\text { Karagöl nâm-1 diğer } \\
\text { Bestam Gölü }\end{array}$ & 6 & - & 0.375 & 0.375 \\
\hline 12 & Diğer Karagöl & 3 & - & 0.25 & 0.25 \\
\hline 13 & Alibijan & 18 & - & 1.50 & 1.50 \\
\hline
\end{tabular}

\footnotetext{
${ }^{65}$ Feridun M. Emecen, "Kayacık Kazâsı Avârız Defteri”, s. 159-160; M. Ali Ünal, “1646 (1056) Tarihli Harput Kazası Avârız Defteri”, Tarih Incelemeleri Dergisi, C. XII, İzmir 1997, s. 9; Şenol Çelik, "1070-1071/1659-1660 Tarihli Avârız Defterine Göre XVII. Yüzyıl Ortalarında Turgutlu Kazası”, Türk Kültürü İncelemeleri Dergisi, sayı 16, İstanbul 2007, s. 38-39.

${ }^{66}$ Mufassal defterde buranın menzil olduğu belirtilip vergiden muaf sayılmıştı, icmal defterde ise yarım avârızhane alındığı belirtilmişti.
} 
Murat Alanoğlu

\begin{tabular}{|c|c|c|c|c|c|}
\hline 14 & Karakurd (Karkarud) & - & 14 & 0.75 & 0.75 \\
\hline 15 & Karamişe & 12 & - & 1 & 1 \\
\hline 16 & Habiban & 8 & - & 0.50 & 0.50 \\
\hline 17 & Bazan & 4 & - & 0.50 & 0.50 \\
\hline 18 & Sultanşeh & 2 & - & 0.25 & 0.25 \\
\hline 19 & Rindali & 3 & - & 0.25 & 0.25 \\
\hline 20 & Kal'acik & 4 & 1 & 0.375 & 0.375 \\
\hline 21 & $\begin{array}{l}\text { Dodan nâm-1 diğer } \\
\text { Hüseyin Şahab }\end{array}$ & 16 & - & 1.25 & 1.25 \\
\hline 22 & $\begin{array}{l}\text { Bazgan nâm-1 diğer } \\
\text { İlyas Köy }\end{array}$ & 10 & - & 0.50 & 0.50 \\
\hline 23 & $\begin{array}{l}\text { Devletşah nâm-1 diğer } \\
\text { Diyadin }\end{array}$ & 14 & - & 0.75 & 0.75 \\
\hline 24 & Güllüce & 4 & - & 0.375 & 0.375 \\
\hline 25 & Karakoç & 5 & - & 0.375 & 0.375 \\
\hline 26 & Çorsan & 2 & - & 0.25 & 0.25 \\
\hline 27 & Okçu Cafer & 13 & - & 0.875 & 0.875 \\
\hline 28 & $\begin{array}{l}\text { Ali Kaç ve } \\
\text { Kızılmescid Mezrası }\end{array}$ & 13 & - & 0.75 & 0.75 \\
\hline 29 & Kizilmescid & 7 & - & 0.50 & 0.50 \\
\hline 30 & Y1lanlı & 4 & - & 0.25 & 0.25 \\
\hline 31 & Armudlu-1 Kebir & 13 & - & 0.625 & 0.625 \\
\hline 32 & Armudlu-1 Sağir & 11 & - & 0.50 & 0.50 \\
\hline 33 & $\begin{array}{l}\text { Üstükran nam-1 diğer } \\
\text { Karatokaç }\end{array}$ & 7 & - & 0.50 & 0.50 \\
\hline 34 & $\begin{array}{l}\text { Armudlu mezra-i } \\
\text { Karatokaç }\end{array}$ & 3 & - & 0.25 & 0.25 \\
\hline \multirow[t]{2}{*}{35} & Haşhaş & 3 & - & 0.25 & 0.25 \\
\hline & Toplam & 243 & 32 & 19.25 Hane & 19.875 Hane \\
\hline
\end{tabular}

1642'de avârız vergi tahsili Erzurum'un diğer yerlerinde nasıl bir seyir takip etmişti? Şimdi diğer kaza ve nahiyelerdeki duruma bakarak Varto ile karşılaştırma imkânı sağlayacak verilere göz atalım. 1642'de Kızuçan kazasında 360 haneden 31,87 avârızhâne toplandığında göre 11 
gerçek hane bir avârızhânesi sayılmıştı. ${ }^{67}$ Yine Erzurum'a bağlı Koğans kazasında 15 gerçek hane bir avârızhânesine tekabül etmekteydi. ${ }^{68}$ Varto'nun hemen doğusunda yer alan Bulanık nahiyesinde 14 köyde toplam 180 hane ikamet etmekteydi. 180 haneden 25 muaf çıkarıldıktan sonra kalan 155 haneden toplanan avârızhâne miktarı 8,75'ti. Buna göre Bulanık'tan yaklaşık olarak 17 gerçek hane bir avârızhane olarak hesaplanmıştı. ${ }^{69} \mathrm{Bu}$ miktar Bulanık'tan toplanan avârız vergisinin Varto'ya göre oldukça düşük olduğunu ve Varto'nun iktisadi yapısının daha iyi durumda olduğunu göstermektedir.

1645 ve 1650 olmak üzere iki yeni icmal kayıt bulunmaktadır. 1645'te Erzurum bölgesinde meydana gelen veba salgını nedeniyle ölenlerin ve köyleri harap olanların eksiklerini kapatmak üzere hem daha önce defter dışı (haric ez defter) kalan yerler yeni sayımda deftere işlenmiş hem de mevcut bazı köylerin vergi miktarı arttırılmıştır. Böylece 1645 tarihli defterlerdeki kayıtlarda görüldüğü üzere Varto'da daha önce kayda geçmeyen beş yeni köy avârız sayımına eklenmiştir. Nitekim 1645'te kaydedilen toplam köy sayısı 39'du ve buradan tahsil edilen avârızhâne miktarı 24 'de çıkmıştı. ${ }^{70}$ Fakat avârız vergisi miktarının bu şekilde arttırılması zaten veba ve sair sıkıntılar nedeniyle zor durumda olan Erzurum halkını bezdirmiş ve halk bu durumu merkeze şikâyetle bildirmişti. Bunun üzerine deftere düşülen kayıtta köylerdeki avârız miktarında indirim yapılması istenmişti. Bu sebeple olacak ki 1650 tarihli kayıtta Varto'da toplam 38 köyden 19.50 avârızhâne vergisi alınmış ve dolayısıyla 4.5 avârızhâne indirimi sağlanmıştı. ${ }^{71}$

sT

Grafik-3: 1642-1650 Yıllarında Varto'da Talep Edilen Avarız Vergisi Miktarı

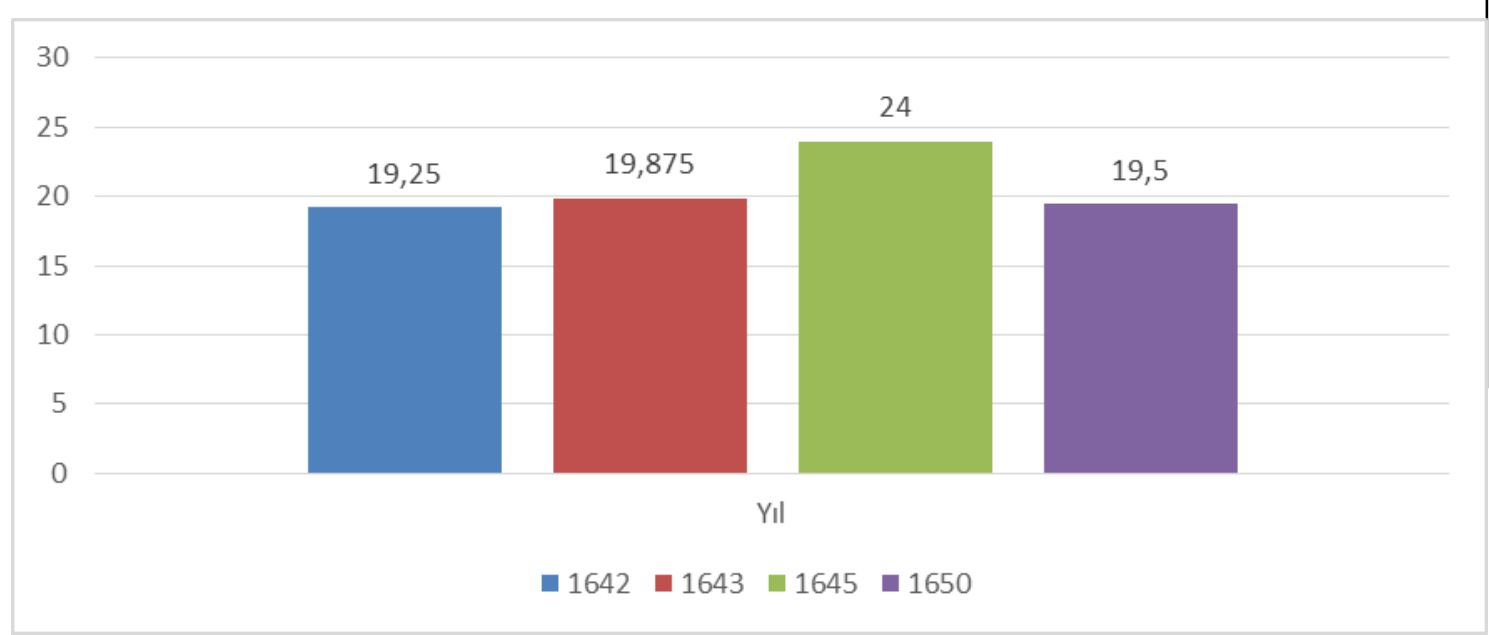

Volume 12

${ }^{67}$ Murat Alanoğlu, “1642 Tarihli Avârız Defterine Göre Kızuçan (Pülümür) Kazâsı”, s. 128.

${ }^{68}$ A. Demir, Koğans Kazası, s. 507.

${ }^{69}$ BOA, MAD. $d$, nr. 5152, s. 870-876.

${ }^{70}$ BOA, MAD. $d$, nr. 14739, s. 43-44.

${ }^{71}$ BOA, MAD. $d$, nr. 14933, s. 49-50. 


\section{Aşiretler ve Yaşadıkları Köyler}

1642 tarihli mufassal defterde Varto'da cemaat başlığıyla kayda geçen dört aşiretin ismine rastlanmaktadır. Her bir köyün adı yazıldıktan sonra yanına "an cemâat-i Zıkdili veya Banûki" ifadesi eklenerek köyün hangi aşirete ait olduğu belirtilmiştir. Bu şekilde Varto'da Z1ktî veya Zıkdili, Banûkî, Pisyan ve Süveydi adıyla dört aşiret kaydedilmiştir. Söz konusu aşiretlere ait bilgiler aşağıdaki şekilde ifade edilebilir.

Zıktî veya Zıkdili: Zaza aşiretlerinden olan Ziktîlerin asıl yerleşimleri Bingöl Genç’ti. 16. yüzyıldan itibaren Ziktî aşireti Genç ve Çabakçur'da yerleşikti. ${ }^{72}$ Nitekim 19. yüzyılda Çabakçur sancağının kazalarından biri Zıktî adını taşımaktaydı. ${ }^{73}$ Osmanlıların Varto'ya hâkimiyet kurmasından sonra Şiî nüfustan boşalan köylere Genç sancağı tarafindan Zıkti aşiretinden bazı aileleri getirip yerleştirdiği düşünülebilir. Çünkü 17. yüzyılda Varto'da en kalabalık aşireti Zıktîler oluşturmaktaydı. Avârız defterine göre Varto'ya bağlı Gestmerd köyünde dört, Govek köyünde yedi, Alagöz köyünde dört, Karagöl veya diğer adıyla Bestam Gölü köyünde altı, Karagöl-i Diğer köyünde dört, Alibijan köyünde dokuz, yine Cemaat-i Zikdili reaya-yı Alibijan şeklinde kaydedilen 16, Dodan veya diğer adıyla Hüseyin Şahab köyünde 20, Güllüce köyünde beş, Çursan köyünde üç hane, Okçu Cafer köyünde 13, Alikaç köyü ile Kızılmescid mezrasında 13 ve Kızılmescid köyünde sekiz hane olmak üzere toplam 113 hane Z1ktî aşiretine mensuptu. Varto'nun toplam hane sayıs1 275 olduğuna göre nüfusun neredeyse yarısını Zıktî aşireti oluşturmaktaydı.

Z1ktî aşiretinin Varto'daki lideri de defterdeki kayıttan öğrenilmektedir. Nitekim Alibijan köyü kaydında ilk hane sahibi olan kişi aynı zaman Zikdili aşiretinin mîr-i aşireti olan Mirza'ydı. Dolayısıyla Varto'da yaşayan Zıktî aşiretine mensup kişileri Mirza Bey idare ve kontrol altında tutmaktayd1. ${ }^{74}$

Banûkî: Varto'daki ikinci büyük aşiret ise Kürt Banûkîlerdi. Karamişe köyünde 15, Habiban köyünde sekiz ve Bazan köyünde dört olmak üzere toplam 27 hane Banûki aşireti üyesi yaşamaktaydı. Banûkî aşiretinin esas yerleşim yerleri Diyarbekir'in Kulp sancağ ${ }^{75}$ olmakla birlikte, yoğun şekilde Hınıs, Bulanık ve Malazgirt bölgesinde yaşadıkları diğer bazı belgelerden öğrenilmektedir. Nitekim Malazgirt'te zaviyesi olan önemli din adamlarından biri Şeyh Hasan Banukî de bu aşirettendi. ${ }^{76}$

Pesyan/Pisyan: Pesyan, asıl yerleşimi Silvan olan Kürt aşiretlerinden biriydi. Bu aşiret belgelerde Bocyan ve Zilan aşiretleri ile birlikte kayda geçmektedir. 17. yüzyılda ağır vergilerden dolayı Diyarbekir bölgesini terk ederek Hınıs, Beyazid ve Kars tarafına göç

\footnotetext{
721550 tarihli Çabakçur tahrir defterinde birçok köyün Zikte/Zikdelü aşiretine ait olduğu kayda geçmiştir. Bkz. 1550 Tarihli Çabakçur Livası: Nüfus ve İskân, Haz. M. Mahfuz Söylemez-Abdullah Demir, Bingöl Belediyesi Kültür Yayınları, Bingöl 2009, s. 154, 160.

${ }^{73}$ BOA, MVL. nr. 711/58; BOA, A. MKT. MVL. nr. 90/99.

${ }^{74} \mathrm{BOA}, M A D . d$, nr. 5152, s. 881 .

${ }^{75}$ BOA, A. DVNS. MHM.d. nr. 7, s. 273.

${ }^{76}$ Bkz. M. Mahfuz Söylemez-A. Demir, Arşiv Belgeleri Işı̆̆ıında Halveti Şeyhi Molla Hasan Banukî ve Zaviyeleri, Araştırma Yayınları, İstanbul 2010.
} 
ettikleri bilinmektedir. ${ }^{77}$ Aşiretin küçük bir kolu da Varto'da Devletşah ya da diğer adıyla Diyadin köyünde yerleşik 14 haneden oluşmaktaydı.

Süveydi: Zaza aşiretlerden biri olan Süveydilerin merkezi Çabakçur, Genç ve Solhan'd1. ${ }^{78}$ Çaldıran Savaşı'ndan sonra Süveydi beyleri Pazukileri mağlup ederek Genç nahiyesini onlardan almışlardı. ${ }^{79} 1642$ defterine yansıdığ 1 üzere Süveydiler Varto bölgesinde de yerleşmişti. Varto'da yerleşik dördüncü aşiret olarak adı geçen Süveydi aşireti Bazgan veya diğer adıyla İlyasköy'de dokuz haneden ibaretti. ${ }^{80}$

Grafik-4: Varto'da Aşiretlerin Hane Sayılar ve Nüfus Yüzdeleri

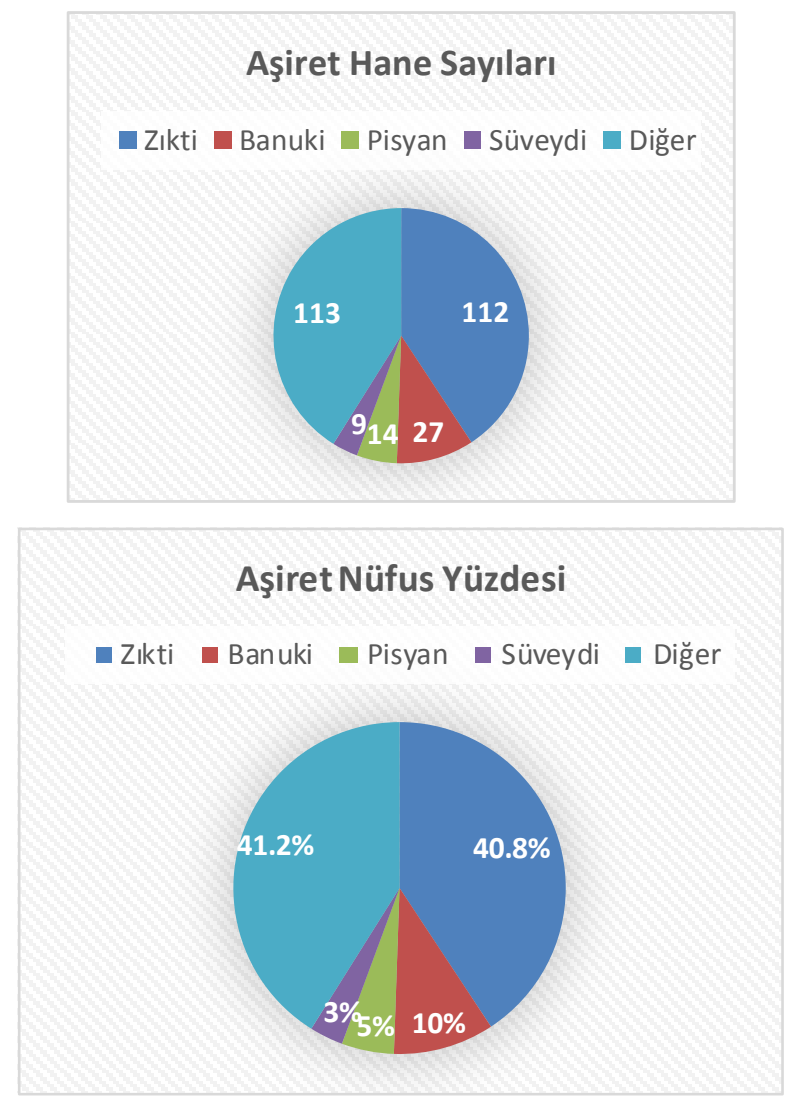

Grafikte görüldüğü üzere Varto'da 17. yüzyıl ortasında dört aşiret kayda geçmiştir. Bunların en büyüğü 113 hane ile nüfusun \%41,2'sini oluşturan Z1kti aşiretiydi. İkinci büyük aşiret ise 27 hane ile nüfusun \%10'unu ihtiva eden Banukilerdi. 14 hane sahibi olan Pisyan aşireti ise nüfusun \%5'ini oluşturmaktaydı. Varto'nun en küçük aşireti ise 9 hane ile nüfusun \%3'ünü meydana getiren Süveydilerdi. Bunların dışında kalan nüfusun \%40'8 ise aşiretsiz veya aşireti belirtilmemiş kimseler ile gayrimüslim halkı meydana getirmekteydi.

\footnotetext{
${ }^{77}$ BOA, C. AS, 899/38700.

${ }^{78}$ Süveydi beylerinin anlatısı için bkz. Şeref Han Bitlisi, Şerefname Kürt Tarihi, C. 1, Farsça'dan çev: Abdullah Yeğin, Nubihar, İstanbul 2013, s. 292-299.

${ }^{79}$ Şerefhan Bitlisi, Şerefnâme, s. 296.

${ }^{80}$ BOA, MAD. $d$, nr. 5152, s. 885 .
} 


\begin{abstract}
Sonuç
17. yüzyıl ortalarında Varto, Erzurum eyaletinin Hınıs sancağına bağlı bir nahiyeydi. Avârız defteri kayıtlarına göre 1642-1650 arasında 35-39 köyden oluşmaktaydı. Köylerin 35'ten 32'sinde Müslümanlar, üçünde Ermeniler yaşamaktaydı. Sadece bir köyde Müslümanlar ile Ermeniler birlikte hayat sürmekteydi. 1642'de Varto'da yerleşik 275 hane bulunmaktaydı. Bu hanelerden 243'ü Müslüman, 32'si Ermeni'ydi. Bu rakamlara bakıldığında 17. yüzyll ortalarında Varto'da Ermeni nüfus \%12, Müslüman nüfus ise \%88 civarındaydı. Dolayısıyla Ermeni kaynaklarında belirtildiğinin aksine 17. yüzyılın ortasında Varto nüfusunun kahir ekseriyeti Müslüman'd1.
\end{abstract}

16. yüzyıl tahrir defterleri ile karşılaştırıldığında 17. yüzyıl ortasında Varto, köy sayısı ve nüfusunun yarısını kaybetmişti. 16. yüzyılda meskûn olan 95 köyden 55-60'1, 17. yüzy1l ortasında 1ssızlaşmış veya terk edilmiş görünmektedir. Zira Varto'da kayda geçen köylerde tahmini olarak 1556'da 1.847 kişi, 1568 'de 3.225 kişi, 1642 'de 1.375 ve bir y1l sonra verilerin güncellendiği 1643 tarihli defterde 1.665 kişi kayıtlıdır. Bu sayılardan da anlaşıldığı üzere 1556'da Safevi tehlikesinin ortadan kalkması ile 1568'e kadar nüfusun \%75 arttı̆ 1 görülmektedir. 17. yüzyılda ise uzun savaşlar, Celali isyanları, veba ve aşırı vergiler gibi sebeplerle nüfus dramatik şekilde düşmüştür. Nitekim Varto'da nüfus 1568 'den 1650'lere kadar \%57 azalmıştır. Orta ve Doğu Anadolu'nun diğer bazı şehirlerinde de görüldüğü üzere 17. yüzyıldaki olumsuz gelişmeler ve güvensiz ortam kırsal köy alanlarının boşalmasına ve çevredeki büyük şehirlere veya Batı Anadolu'ya göç etmesine sebep olmuştur. Varto'da da durum bu şekilde seyretmiş hem Ermeniler hem de Müslümanlar yerlerini terk ederek başka diyarlara göç etmişlerdir. Varto'dan göç edenlerin nereye gittikleri konusu ise şimdilik yanıtını bekleyen bir soru olarak kalmaktadır.

Varto'da köylerin Bingöl, Şerafettin ve Hamurpet dağları arasındaki yükseltinin azaldığ plato ve düzlük alanlara kurulduğu görülmektedir. Daha ziyade akarsu vadilerinde ve dağların alçalmaya başladığı tepelik yayla alanlarında köyler ve mezralar yer almaktadır. Köyler oldukça seyrek nüfusluydu, en kalabalık köyler 10-20 hane arasında iken birçok köy iki-üç haneden oluşmaktaydi.

Varto'dan toplanan avârızhâne miktarına bakıldığında bölgenin ekonomik koşullarının ve üretim gücünün oldukça düşük olduğu sonucuna varılabilir. Varto'nun tarım, sanayi ve ticarete uygun olmayan coğrafi yapısı bunun en temel nedeniydi. Varto'da 13 gerçek hane 1 avârızhânesi sayılmıştı. Varto'da vergiden muaf olan kişi sayısı 275 haneden 26'd1. Bunların altısı din adamı, üçü sipahizâde, 13'ü erbâb-1 timardı. Sadece bir kişi yoksul olduğundan avârız vergisinden hariç tutulmuştu. Varto'da engelli herhangi bir kişi kayda geçmemişti.

17. yüzyılda Varto'nun sosyo-iktisadi hayatına yön veren dört aşiret bulunmaktaydı. Bunlardan Ziktî aşireti 14 köyde 113 haneden mürekkepti. Varto nüfusunun önemli bir kısmını bu Zaza aşireti oluşturmaktayd. İkinci aşiret olan Banukîler, üç köyde toplam 27 haneden meydana gelmekteydi. Pisyan aşireti tek bir köyde 14 haneden ibaretti. En az nüfusa sahip olan Süveydiler de yalnız bir köyde dokuz haneden oluşmaktaydı. 17. yüzyılda kayda geçen bu aşiretlere bakıldığında günümüz Varto'sunu oluşturan Hormek, Lolan ve Cibran gibi aşiretlerin henüz Varto'ya gelmedikleri bunun 1650 'lerden sonra gelişecek bir nüfus ve göç hareketine 
bağlı olduğu söylenebilir. Dolayısıyla mevcut literatürde dolaşımda olan bu yanlış bilginin de çalı̧̧mada elde edilen yeni veriler çerçevesinde tashih edilmesi gerekmektedir.

\section{Kaynakça}

\section{A. Arşiv Belgeleri}

Devlet Arşivleri Başkanlığı Osmanlı Arşivi (BOA)

A. AMD. 86/66.

A. MKT. MVL. 90/99, 85/57, 85/8.

BEO. $13 / 944$.

C. AS. 899/38700.

D. MKF.d. 31738 .

HAT. 769/36172; 814/37264.

MAD. d. 22171, 5152, 6422, 14933, 14739.

MVL. 711/58.

A.DVNS. MHM. d, 7.

TT. d. 64, 70, 189, 294, 231.

\section{B. Salnameler}

Sâlnâme-i Vilâyet-i Bitlis, 1310.

Sâlnâme-i Devlet-i Aliyye-i Osmaniyye, 1263, 1264.

Sâlnâme-i Vilâyet-i Erzurum, 1287, 1288, 1289, 1290, 1291,1875, 1293.

\section{Yayımlanmış Arşiv Kaynakları}

1550 Tarihli Çabakçur Livası: Nüfus ve İskân, Haz. M. Mahfuz Söylemez-Abdullah Demir, Bingöl Belediyesi Kültür Yayınları, Bingöl 2009.

294 Numaralı Hınıs Livâsı Mufassal Tahrir Defteri (963/1556), Ankara 2000.

Dâhiliye Vekâleti, Son Teşkilât-ı Mülkîyede Köylerimizin Adları, Millet Matbaası 1928.

1642 Tarihli Erzurum Eyaleti Mufassal Avârız Defteri I (Erzurum-Tortum-İsbir-Hınıs -Pasin), Haz. Mehmet İnbaş1-İbrahim E. Çakır-Selçuk Demir, TTK, Ankara 2014.

\section{Kaynak ve Araștırma Eserler}

AKBAL, Fazıla, "1831 Tarihinde Osmanlı İmparatorluğu'nda İdari Taksimat ve Nüfus", Belleten, C. 15/60, Ankara 1951, s. 617-628.

ALANOĞLU, Murat, "1642 Tarihli Avârız Defterine Göre Kızuçan (Pülümür) Kazâsı”, Tarih Okulu Dergisi, Y11 9, say1 XXVIII, Aralık 2016, s. 109-140.

AYDIN, Dündar, Erzurum Beylerbeyliği ve Teşkilatı Kuruluş ve Genişleme Devri (1535-1566), TTK, Ankara 1998. 
BARKAN, Ö. Lütfi “Tarihî Demografî Araştırmaları ve Osmanlı Tarihi”, Türkiyat Mecmuası, C. X (1951-1953), S. 1-24.

BARKAN, Ö. Lütfi, “Avârız”, İA, C. 2, İstanbul 1979, s. 13-19.

BELLAİGUE, Christopher de, İsyan Toprakları: Türkiye'nin Unutulmuş Halkları Arasında, İletişim Yayınları, İstanbul 2016.

BURNEY, C. A., "A First Season of Excavations on the Urartian Citadel of Kayalidere”, Anatolian Studies, 16 (1966), s. 55-111.

ÇELIK, Şenol, “1070-1071/1659-1660 Tarihli Avârız Defterine Göre XVII. Yüzyıl Ortalarında Turgutlu Kazası”, Türk Kültürü İncelemeleri Dergisi, say1 16, İstanbul 2007, s. 33-66.

DARLING, Linda T., Gelir Artışı ve Kanuna Uygunluk, Osmanlı Imparatorluğunda Vergi Toplanması ve Maliye Yöntemi 1560-1660, Çev. Adnan Tonguç, Alfa, İstanbul 2019.

DEMİ, Alparslan,"1642 Tarihli Avârız Defterine Göre Koğans Kazâsı”, Gaziantep Üniversitesi Sosyal Bilimler Dergisi, say1 11/2, Gaziantep 2012, s. 505-529.

DEMİR, Selçuk-ÇAKIR, İbrahim E., "Tercan Kazası (1591-1642)”, Karadeniz Araştırmaları, say1 50, Yaz 2016, s. 153-175.

EMECEN, Feridun M., "Kayacık Kazâsı Avârız Defteri”, Tarih Enstitüsü Dergisi, sayı 12, İstanbul 1981-1982, s. 159-170.

FIRAT, M. Şerif, Doğu İlleri ve Varto Tarihi, Kamer, İstanbul 1998.

GÖYÜNÇ, Nejat, "Hâne Deyimi Hakkında”, Tarih Dergisi, C. 32 (1979), s. 331-348.

GÜLER, Yasin, Varto Kasabasının Coğrafi Etüdü, Yayımlanmamış Yüksek Lisans Tezi, Atatürk Üniversitesi, Sosyal Bilimler Enstitüsü, Erzurum 2003.

İNBAŞI, Mehmet, "1642 Tarihli Avârız Defterine Göre Bayburt Sancağı”, A.Ü. Sosyal Bilimler Enstitüsü Dergisi, C. X, sayı 2, Erzurum 2007, s. 89-117.

İNBAŞI, Mehmet, "1642 Tarihli Avârız Defterine Göre Erzurum Şehri”, Türk Kültürü Incelemeleri Dergisi, say1 4, İstanbul 2001, s. 9-32.

İNBAŞI, Mehmet, "Erzincan Kazası (1642 Tarihli Avârız Defterine Göre), A.Ü. Türkiyat Araştırmaları Dergisi, sayı 41, Erzurum 2009, s. 189-214. 
17. Yüzyıl Ortalarında Varto (Yerleşim, Nüfus, Vergi ve Aşiretler)

KILIÇ, Ümit, "Erzurum'da Câfer Efendi Vakf1”, A.Ü. Türkiyat Araştırmaları Enstitüsü Dergisi, say1 41, Erzurum 2009, s. 173-187.

KOÇAK, Zülfiye, “Tapu Tahrir Defterlerine Göre XVI. Yüzyılda Varto Nahiyesi”, Osmanlı Mirası Araştırmaları Dergisi, C. 5, sayı 13, Kasım 2018, s. 219-253.

KUL, Eyüp, "1642 Tarihli Avârız Defterine Göre Şiran Kazâsı ve Köyleri”, A.Ü. Türkiyat Araştırmaları Enstitüsü Dergisi, sayı 44, Erzurum 2010, s. 271-289.

ÖZBEY, Mustafa, Osmanlı Belgelerinde Varto İlçesi, Doz Yayınları, İstanbul 2010.

ÖZDEMIR, Rifat, "Avârız ve Gerçek-Hâne Sayılarının Demografik Tahminlerde Kullanılması Üzerine Bazı Bilgiler”, X. Türk Tarih Kongresi, Ankara, 22-26 Eylül 1986, Kongreye Sunulan Bildiriler, C. IV, Ankara 1993, s. 1581- 1613.

ÖZEL, Oktay, “17. Yüzyıl Osmanlı Demografi ve İskân Tarihi İçin Önemli Bir Kaynak: Mufassal Avârız Defterleri”, XII. Türk Tarih Kongresi (12-16 Eylül 1994) Kongreye Sunulan Bildiriler, C. III, Ankara 1999, s.735-744.

ÖZEL, Oktay, “Avârız ve Cizye Defterleri”, Osmanlı Devleti'nde Bilgi ve İstatistik, Ed. Halil İnalcık-Şevket Pamuk, Ankara 2000, s. 35-50.

PAMUK, Bilgehan, "Gümüşhâne (Torul) Kazası", Belleten, C. LXXIII/266, Ankara 2009, s. 115-143.

PAMUK, Bilgehan, XVII. Yüzyılda Bir Serhad Şehri Erzurum, IQ Kültür Sanat Yayıncılık, İstanbul 2006.

SAĞLAM, Nevzat, "5152 Nolu ve H. 1052/M. 1642 Tarihli Maliyeden Müdevver Deftere Göre Kiğı ve Köylerinde İskân ve Nüfus”, II. Bingöl Sempozyumu Bildirileri, Yeni Zaman Sahaf: Ankara 2009, s. 295-346.

SARAÇOĞLU, Hüseyin, Doğu Anadolu, C. 1, Maarif Yayınevi, İstanbul 1956.

SÖYLEMEZ, M. Mahfuz -A. Demir, Arşiv Belgeleri Işı̆ğında Halveti Şeyhi Molla Hasan Banukî ve Zaviyeleri, Araştırma Yayınları, İstanbul 2010.

BİTLİSI, Şeref Han, Şerefname Kürt Tarihi, C. 1, Farsça'dan Çeviren: Abdullah Yeğin, Nubihar, İstanbul 2013.

ÜNAL, M. Ali, “1646 (1056) Tarihli Harput Kazası Avârız Defteri”, Tarih Incelemeleri Dergisi, C. XII, İzmir 1997, s. 9-73. 


\section{E. İnternet Kaynakları}

http://www.mus.gov.tr/varto-mus Erişim Tarihi: 30.10.2019.

https://nisanyanmap.com/?yer=25708\&haritasi=s\%C4\%B1radere Erişim tarihi: 30.10.2019.

HISTORY

STUDIES

1173

Volume 12

Issue 3

June

2020 


\section{EKLER:}

EK-1: 5152 Numaral1 1642 Tarihli Erzurum Eyaleti Mufassal Avarız Defterinde Varto'ya Ait İlk ve Son Sayfa

890

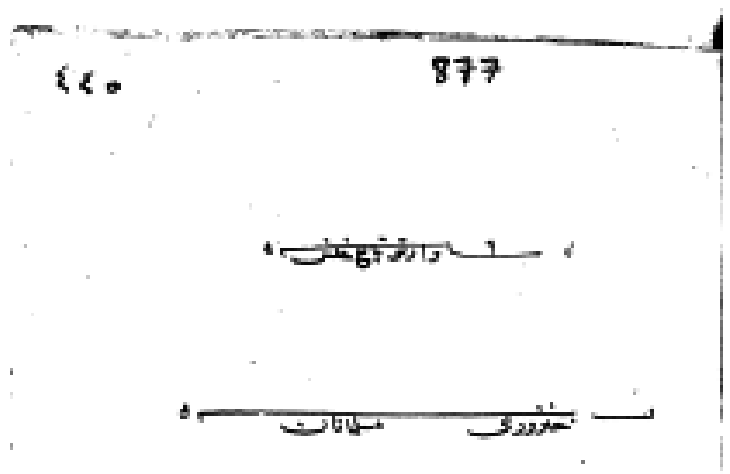

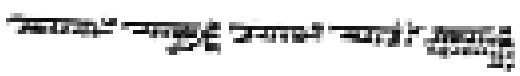
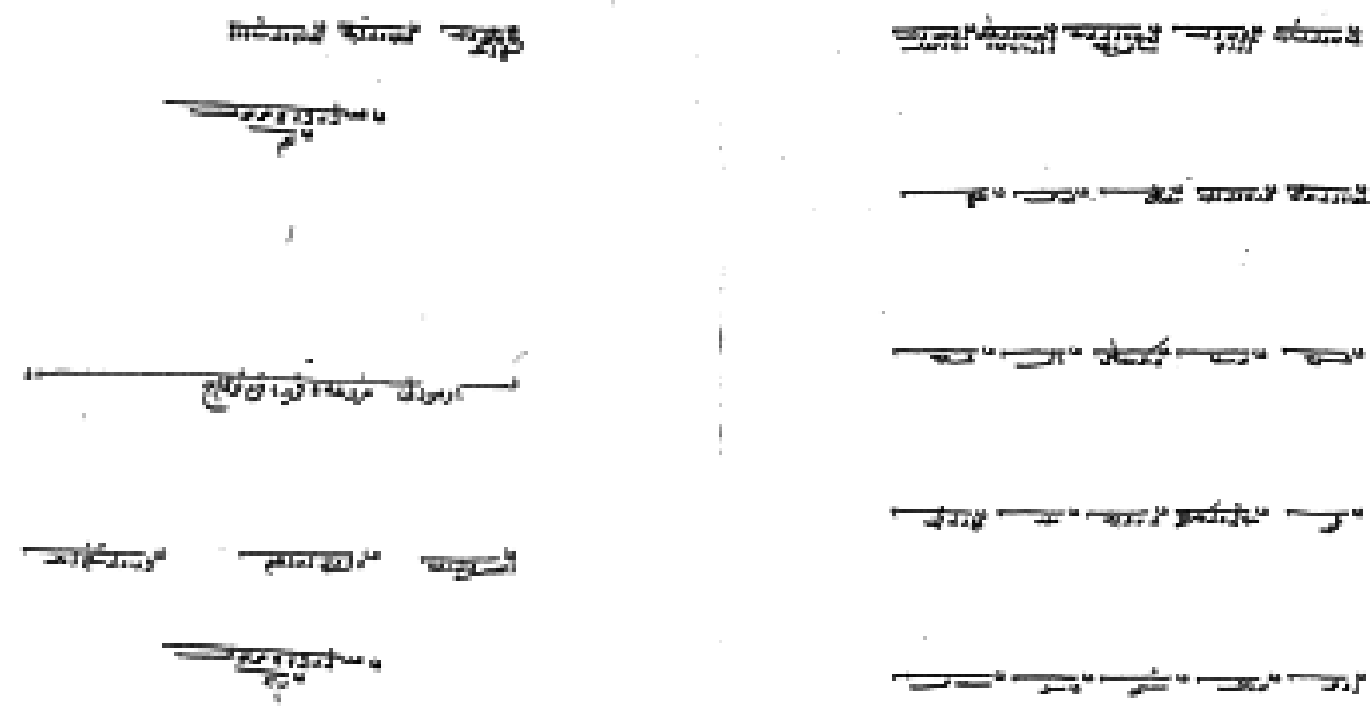

HISTORY
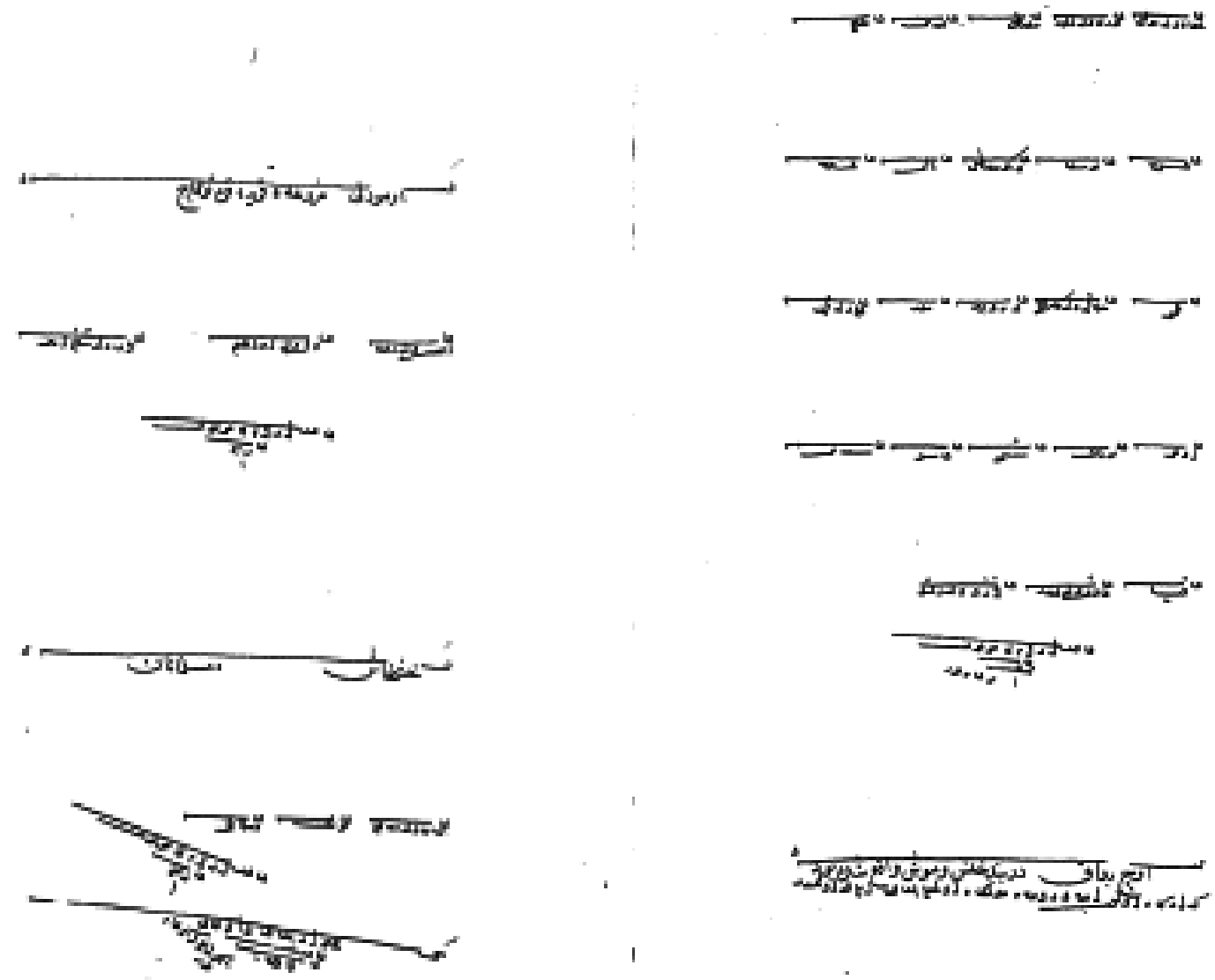


\section{Murat Alanoğlu}

EK-2: 17. Yüzyıl Ortasında Kayda Geçen Varto Köyleri ve Fiziki Coğrafya

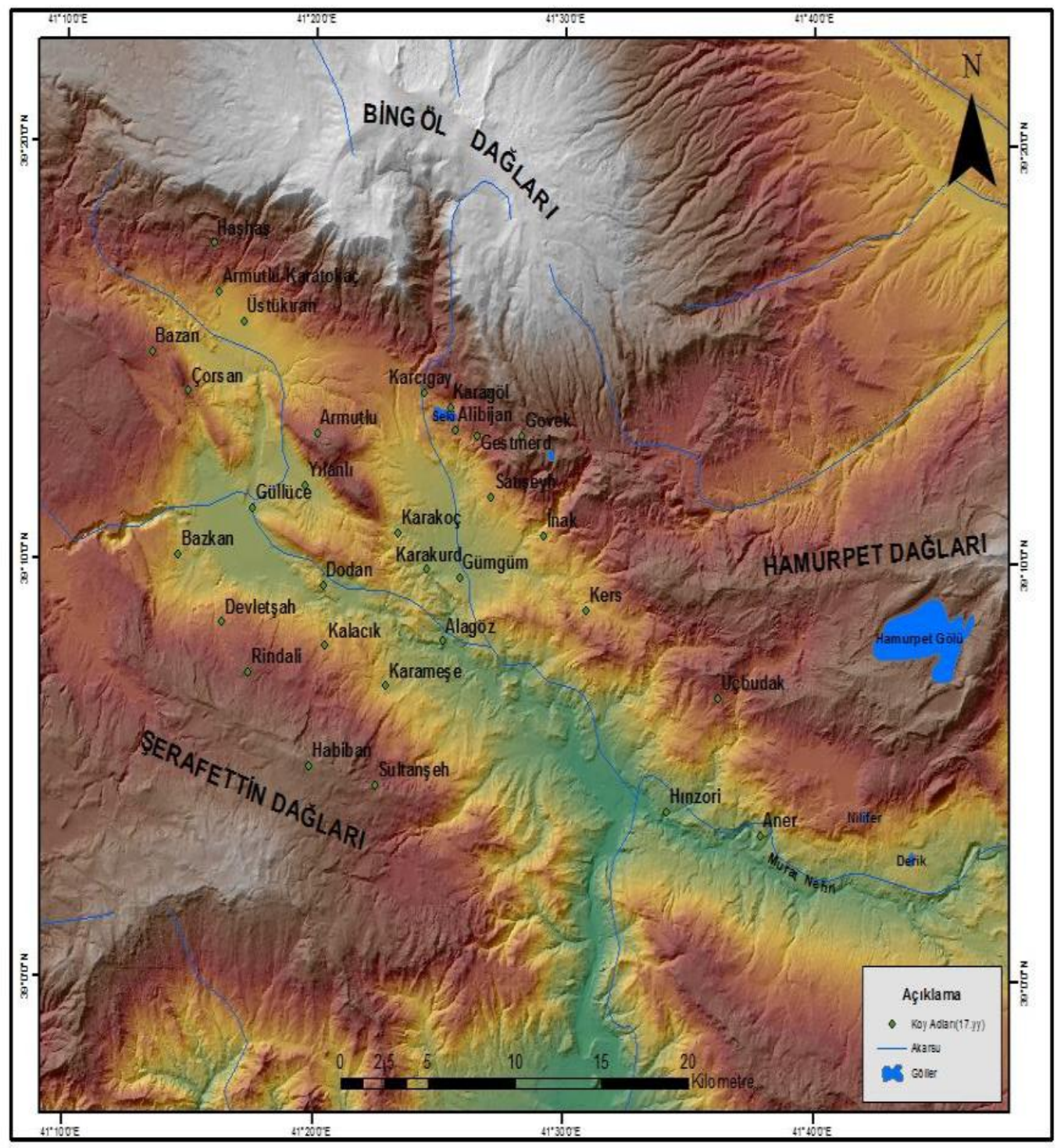

